\title{
Nanopore Structure and Fractal Characteristics of Lacustrine Shale: Implications for Shale Gas Storage and Production Potential
}

\author{
Lei Chen ${ }^{1,2,3}$, Zhenxue Jiang ${ }^{1,2, *}$, Shu Jiang ${ }^{3,4, *}, \mathbb{D}$, Keyu Liu ${ }^{5}$, Wei Yang ${ }^{1,2, *}$, Jingqiang Tan ${ }^{6}$ \\ and Fenglin Gao ${ }^{1,2}$
}

1 State Key Laboratory of Petroleum Resources and Prospecting, China University of Petroleum, Beijing 102249, China; chenlei19880804@163.com (L.C.); u6016291@utah.edu (F.G.)

2 Unconventional Oil \& Gas Cooperative Innovation Center, China University of Petroleum, Beijing 102249, China

3 Energy \& Geoscience Institute, University of Utah, Salt Lake City, UT 84108, USA

4 Key Laboratory of Tectonics and Petroleum Resources, Ministry of Education, China University of Geosciences, Wuhan 430074, China

5 School of Geosciences, China University of Petroleum, Qingdao 266580, Shandong, China; keyu_liu@icloud.com

6 School of Geosciences and Info-physics, Central South University, Changsha 410012, China; tanjingqiang@aliyun.com

* Correspondence: jiangzx@cup.edu.cn (Z.J.); sjiang@egi.utah.edu (S.J.); yangw@cup.edu.cn (W.Y.); Tel.: +86-10-8973-3328 (Z.J.); +1-801-585-9816 (S.J.); +86-10-8973-9051 (W.Y.)

Received: 13 February 2019; Accepted: 26 February 2019; Published: 7 March 2019

\begin{abstract}
In order to better understand nanopore structure and fractal characteristics of lacustrine shale, nine shale samples from the Da'anzhai Member of Lower Jurassic Ziliujing Formation in the Sichuan Basin, southwestern (SW) China were investigated by total organic carbon (TOC) analysis, X-ray diffraction (XRD) analysis, field emission scanning electron microscopy (FE-SEM), and low-pressure $\mathrm{N}_{2}$ adsorption. Two fractal dimensions $\mathrm{D}_{1}$ and $\mathrm{D}_{2}$ (at the relative pressure of $0-0.5$ and $0.5-1$, respectively) were calculated from $\mathrm{N}_{2}$ adsorption isotherms using the Frenkel-Halsey-Hill $(\mathrm{FHH})$ equation. The pore structure of the Lower Jurassic lacustrine shale was characterized, and the fractal characteristics and their controlling factors were investigated. Then the effect of fractal dimensions on shale gas storage and production potential was discussed. The results indicate that: (1) Pore types in shale are mainly organic-matter $(\mathrm{OM})$ and interparticle (interP) pores, along with a small amount of intraparticle (intraP) pores, and that not all grains of $\mathrm{OM}$ have the same porosity. The Brunauer-Emmett-Teller (BET) surface areas of shale samples range from 4.10 to $8.38 \mathrm{~m}^{2} / \mathrm{g}$, the density-functional-theory (DFT) pore volumes range from 0.0076 to $0.0128 \mathrm{~cm}^{3} / \mathrm{g}$, and average pore diameters range from 5.56 to $10.48 \mathrm{~nm}$. (2) The BET surface area shows a positive correlation with clay minerals content and quartz content, but no obvious relationship with TOC content. The DFT pore volume shows a positive correlation with TOC content and clay minerals content, but a negative relationship with quartz content. In addition, the average pore diameter shows a positive correlation with TOC content and a negative relationship with quartz content, but no obvious relationship with clay minerals content. (3) Fractal dimension $\mathrm{D}_{1}$ is mainly closely associated with the specific surface area of shale, suggesting that $D_{1}$ may represent the pore surface fractal dimension. Whereas fractal dimension $\mathrm{D}_{2}$ is sensitive to multiple parameters including the specific surface area, pore volume, and average pore diameter, suggesting that $\mathrm{D}_{2}$ may represent the pore structure fractal dimension. (4) Shale with a large fractal dimension $\mathrm{D}_{1}$ and a moderate fractal dimension $\mathrm{D}_{2}$ has a strong capacity to store both adsorbed gas and free gas, and it also facilitates the exploitation and production of shale gas.
\end{abstract}


Keywords: shale gas; pore structure; fractal characteristics; lacustrine shale; Sichuan Basin

\section{Introduction}

With a severe energy shortage situation, increasing shale gas has received more attention worldwide, and a global astounding "shale gas green revolution" is booming in the past few years. More than 20 countries except for the North America are conducting prophase evaluation and pilot test of shale gas exploration and development, especially in China [1-5]. Shale gas resource has already become a natural gas production target with great potential and of great significance. In order to encourage and accelerate the exploration of shale gas, the Government of China introduced relevant policies to take shale gas as a new type of mineral resource in 2011.

The shale reservoir is an extremely tight reservoir characterized by strong heterogeneous, ultra-low porosity and permeability with abundant nanoscale pores [6-8]. Except that a small amount of shale gas occurs as dissolved gas in residual oil and water, most of shale gas occurs as adsorbed gas in organic matters and clay minerals or occurs as free gas in pores and fractures [9-12]. Shale reservoir research is one of the important tasks in the geological evaluation of shale gas [1]. It can provide a sufficient basis for shale gas exploration and development by investigating the reservoir spatial distribution characteristics and the occurrence state of natural gas. The pore structure characteristics are important factors in determining shale gas storage capacity and are one of the key parameters for shale reservoir evaluation and shale gas resources evaluation $[9,11,13-15]$. The pore structure of shale can be characterized by multiple parameters such as pore size, pore morphology, pore volume, specific surface area, and spatial distribution $[6,7,11,15-18]$. Accurately measuring these pore structure parameters and investigating their controlling factors are of great significance for the study of the shale gas accumulation mechanism.

At present, many methods can be used to investigate the pore structure characteristics of shale. Through scanning electron microscopy (SEM), field emission scanning electron microscopy (FE-SEM), environmental scanning electron microscopy (ESEM), focused ion beam-scanning electron microscopy (FIB-SEM), broad ion beam-scanning electron microscopy (BIB-SEM), transmission electron microscopy (TEM), nano-computed tomography (nano-CT), and other high-resolution observation equipment, the morphology, size, distribution, and connectivity of pores can be observed, and the qualitative characterization of pore structure of shale can be achieved [6-8,14,15,17-26]. Low-pressure gas adsorption, high-pressure mercury intrusion porosimetry (MIP), nuclear magnetic resonance (NMR), and small-angle neutron scattering (SANS) methods can not only quantitatively characterize the pore size distribution of shale, but also obtain the total pore volume, specific surface area, and other parameters $[9,15,16,27-34]$. Among them, low-pressure $\mathrm{N}_{2}$ adsorption has been proved highly effective in the pore structure characterization of shale. In recent years, more and more research have been conducted on the pore fractal characteristics of shale using $\mathrm{N}_{2}$ adsorption isotherms [35-41].

Fractal theory is a nonlinear mathematical theory firstly introduced by Mandelbrot in 1975 [42]. Now it has become a powerful tool to characterize the pore surface and pore structure characteristics of shale. In recent years, with the large-scale development of shale gas in North America and China, some scholars have conducted exploratory studies on pore structure and fractal characteristics of shale reservoirs [36-38,43-45]. The Frenkel-Halsey-Hill (FHH) fractal theory provides a new method for the quantitative study of pore structure in shale, which can be used to obtain the spatial distribution characteristic parameters of pore structure [44,45]. In general, current studies mainly focus on marine shale $[36,37,39,41,43,44]$, whereas limited research has been done on the pore structure and fractal characteristics in lacustrine shale. The lacustrine shale reservoir is usually characterized with a small single layer thickness and a large cumulative thickness [46]. For example, for the studied lacustrine shale in this paper, the effective thickness ranges from $30 \mathrm{~m}$ to $70 \mathrm{~m}$. It varies frequently in lithology and is commonly interbedded with the sandstone or limestone due to frequent changes in the lake 
level [47]. The maturity of organic matter is lower than that of marine shale, and the types of organic matter are mainly types $\mathrm{II}_{2}$ and III, which are relatively poor in hydrogen [3,46]. Different sedimentary environments also lead to the differences in the pore characteristics between lacustrine shale and marine shale. Therefore, it is very necessary to investigate the pore structure and fractal characteristics to fully understand the geological characteristics of lacustrine shale.

This study focuses on the lacustrine shale from the Lower Jurassic Da'anzhai Member in the Sichuan Basin, SW China. In order to investigate the pore structure and fractal characteristics of shale, FE-SEM and low-pressure $\mathrm{N}_{2}$ adsorption experiments combined with the FHH theory for shale samples were selected to be conducted. The main objectives of this study were to: (1) characterize the pore structure of the Lower Jurassic lacustrine shale; (2) investigate the fractal characteristics and their controlling factors; and (3) discuss the effect of fractal dimensions on shale gas storage and production potential. Our studies can provide a new research idea and method for the assessment and exploitation of natural gas in the lacustrine shale reservoirs.

\section{Samples and Methods}

\subsection{Geological Setting and Samples}

The Sichuan Basin covers a vast area of the eastern Sichuan province and most of the Chongqing metropolitan region (Figure 1). It is a tectonically stable and superimposed petroliferous basin which is located in the western region of the Yangtze craton, SW China. It covers an area of more than $180,000 \mathrm{~km}^{2}$ with a diamond shape and a northeast trend. At present, a lot of oil fields and gas fields have been found in the Sichuan Basin. It is a multiple-cycle sedimentary basin which is bounded by the Longmen Mountain (fold belt) in the northwest, the Micang Mountain (uplift) and Daba Mountain (fold belt) in the north, and the Daxiangling and Dalou Mountains in the south [48].

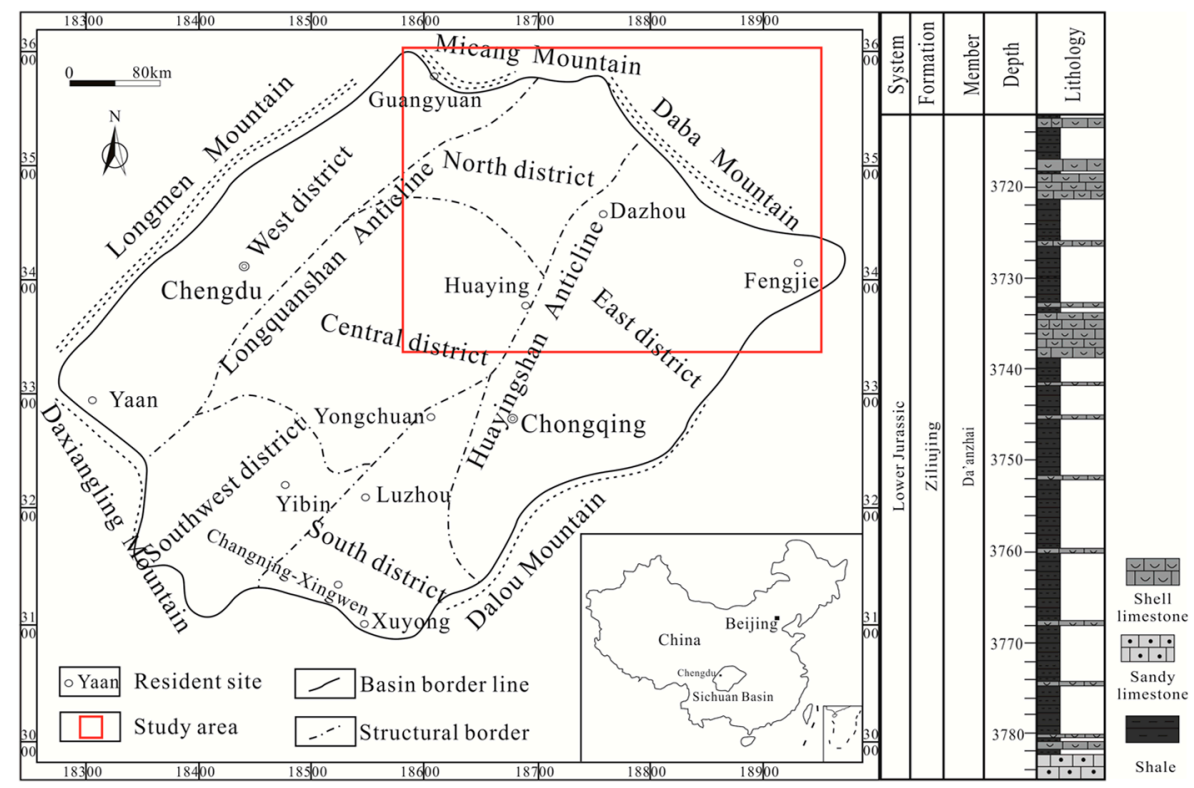

Figure 1. Study location, geological map, and simplified stratigraphic column of the Jurassic Da'anzhai Member in the northeastern Sichuan Basin.

The study area is located in the northeastern Sichuan Basin (Figure 1), which includes the Huaying and Dazhou areas. During the Jurassic Period, the Sichuan Basin was dominated by a lacustrine environment, and the Da'anzhai Member represents the largest and deepest stage of this environment [49], forming a large set of shale [47,49]. In addition, the Jurassic Da'anzhai Member shale formation varies frequently in lithology and is commonly interbedded with the shell limestone or sandy limestone due to frequent changes in the lake level during the Da'anzhai period (Figure 1). The studied 
shale samples originated from the Da'anzhai Member of Lower Jurassic Ziliujing Formation in the northeastern Sichuan Basin, SW China. All the shale samples were collected from fresh core materials. About 100-200 g were weighed for each sample, most of them were crushed to less than 60 mesh size with sufficiently mixed. Prior to the experiments, the samples were dried under vacuum at $110{ }^{\circ} \mathrm{C}$ for at least $12 \mathrm{~h}$. Samples information such as ID, TOC and other geological parameters are listed in Table 1.

Table 1. Total organic carbon (TOC), mineralogical composition, and pore structure parameters of shale samples.

\begin{tabular}{|c|c|c|c|c|c|c|c|c|c|c|}
\hline \multirow{2}{*}{$\begin{array}{l}\text { Sample } \\
\text { ID }\end{array}$} & \multirow{2}{*}{$\begin{array}{l}\text { Depth } \\
\text { (m) }\end{array}$} & \multirow{2}{*}{$\begin{array}{c}\text { TOC } \\
(\%)\end{array}$} & \multicolumn{5}{|c|}{ Mineralogical Composition Relative Percentage (\%) } & \multirow{2}{*}{$\begin{array}{l}\text { BET Surface } \\
\text { Area }\left(\mathrm{m}^{2} / \mathrm{g}\right)\end{array}$} & \multirow{2}{*}{$\begin{array}{c}\text { DFT Pore } \\
\text { Volume }\left(\mathrm{cm}^{3} / \mathrm{g}\right)\end{array}$} & \multirow{2}{*}{$\begin{array}{l}\text { Average Pore } \\
\text { Diameter }(\mathrm{nm})\end{array}$} \\
\hline & & & Quartz & Feldspar & Carbonates & Pyrite & Total Clays & & & \\
\hline Y-1 & 3963.0 & 0.73 & 49.2 & 2.1 & 10.2 & 0 & 38.5 & 4.30 & 0.0076 & 7.80 \\
\hline Y-2 & 3964.2 & 0.39 & 37.1 & 1.9 & 21.3 & 0 & 39.7 & 5.31 & 0.0087 & 6.99 \\
\hline $\mathrm{Y}-4$ & 3966.1 & 0.54 & 49.1 & 2.7 & 4.2 & 0 & 44.0 & 6.67 & 0.0093 & 5.97 \\
\hline Y-5 & 3967.2 & 0.99 & 57.1 & 1.9 & 8.7 & 0 & 32.3 & 5.27 & 0.0081 & 6.80 \\
\hline Y-6 & 3968.4 & 0.97 & 36.4 & 5.2 & 10.1 & 1.2 & 47.1 & 5.76 & 0.0113 & 8.51 \\
\hline Y-9 & 3970.8 & 0.74 & 38.6 & 5.8 & 6.9 & 1.1 & 47.6 & 6.79 & 0.0091 & 5.70 \\
\hline
\end{tabular}

\subsection{X-ray Diffraction Analysis}

The mineralogical composition of the shale samples with the usage of the Ultima IV full-automatic powder X-ray diffraction (XRD) analyzer (Rigaku, Tokyo, Japan) was completed at Experimental Research Center of East China Branch, SINOPEC (Nanjing, China).

The shale sample to be tested was first crushed, then from which about $5 \mathrm{~g}$ was moved into a mortar before being ground to about 300 mesh. The ground sample was divided into two parts with one for XRD analysis and the other being left in reserve in case obvious human error occurred in the experimental test process. During the experiment, the qualitative analysis was performed to determine the sample composition using the standard powder diffraction data provided by the Joint Committee of Powder Diffraction Standards of the International Centre for Diffraction Data (JCPDS-ICDD). The quantitative analysis was carried out to obtain the mineral composition and content of the shale samples in which the K-value method of China National Standard (GB 5225-86) was adopted.

\subsection{FE-SEM Observation}

The FE-SEM observation was conducted in Institute of Geology and Geophysics, Chinese Academy of Sciences (Beijing, China). A NanoFab ORION microscope made by Carl Zeiss, Jena, Germany, was used to observe the pore morphology of shale samples. It could produce images of the pore structure with a high resolution of $0.8 \mathrm{~nm}$ (at $40 \mathrm{kV}$ operating voltage and high-vacuum mode). Prior to the experiment, in order to produce a smooth sample surface, grinding and Ar-ion polishing were need to be conducted. This method avoids the damage of sample surface caused by mechanical polishing processes and preserves the real pore morphology of the sample surface.

\subsection{Low-Pressure $\mathrm{N}_{2}$ Adsorption}

Low-pressure (<0.127 MPa) $\mathrm{N}_{2}$ adsorption analyses were performed by using a Micromeritics ${ }^{\circledR}$ Tristar II 3020 surface area analyzer (Micromeritics Instrument, Norcross, GA, USA). at State Key Laboratory of Heavy Oil Processing in China University of Petroleum, Beijing.

Shale sample aliquots weighing 1 to $2 \mathrm{~g}$ were analyzed with $\mathrm{N}_{2}$ to obtain information about microscopic pore structure. Samples were automatically degassed at about $110^{\circ} \mathrm{C}$ under vacuum for about $14 \mathrm{~h}$ to remove adsorbed moisture and volatile matter before analyzing with $\mathrm{N}_{2}$. For quantifying $\mathrm{N}_{2}$ adsorption, the sample was kept at the temperature of liquid nitrogen $(77.35 \mathrm{~K}$ at $101.3 \mathrm{kPa})$. The relative pressure $\left(P / P_{0}\right)$ for $\mathrm{N}_{2}$ adsorption ranges from 0.001 to 0.995 . The instrument's computer 
software automatically generates adsorption isotherms and calculates surface areas, pore volumes, and pore size distributions based on multiple adsorption theories [32,33,50].

\section{Results}

\subsection{Mineralogical Composition Determination by XRD}

As shown in Table 1 and Figure 2, the mineralogy of shale samples is complicated, and therefore the contents of each component from different samples vary significantly. The shale samples contain abundant quartz and clay minerals. The total clay minerals contents range from $32.3 \%$ to $54.4 \%$ with both temporal and spatial variation. The clay minerals generally reflect the diagenetic evolution and depositional environments and they are important to the study of methane storage capacity of shale. In addition to clay minerals, quartz is also the major mineral in the shale samples with a percentage of $25.5 \%-57.1 \%$. Feldspar and carbonates are in significant quantities in the shale samples with a range of $1.9 \%-6.2 \%$ and $3.9 \%-23.9 \%$, respectively. Pyrite occurs occasionally with a percentage of $0.6 \%-4.0 \%$.

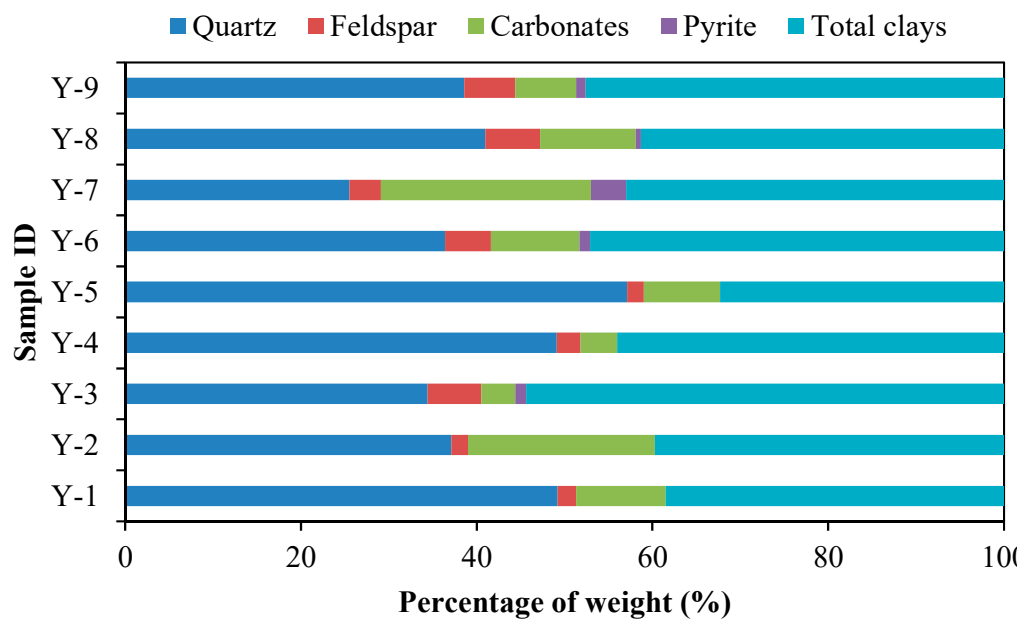

Figure 2. Mineralogical compositions of the shale samples.

As shown in Figure 3A, TOC content shows a decreasing trend with the increase of quartz content, which is different from the strong positive correlation observed in marine shale samples [9,15,51-53]. This difference may be related to different quartz sources resulted from the differences in sedimentary environments of shale. The Da'anzhai Member shale is a product of lacustrine sedimentary environment and the quartz is primarily clastic in origin $[49,54]$. In addition, as shown in Figure 3B, there is no significant relationship between TOC content and total clays content, which may be related to the lacustrine sedimentary environment.
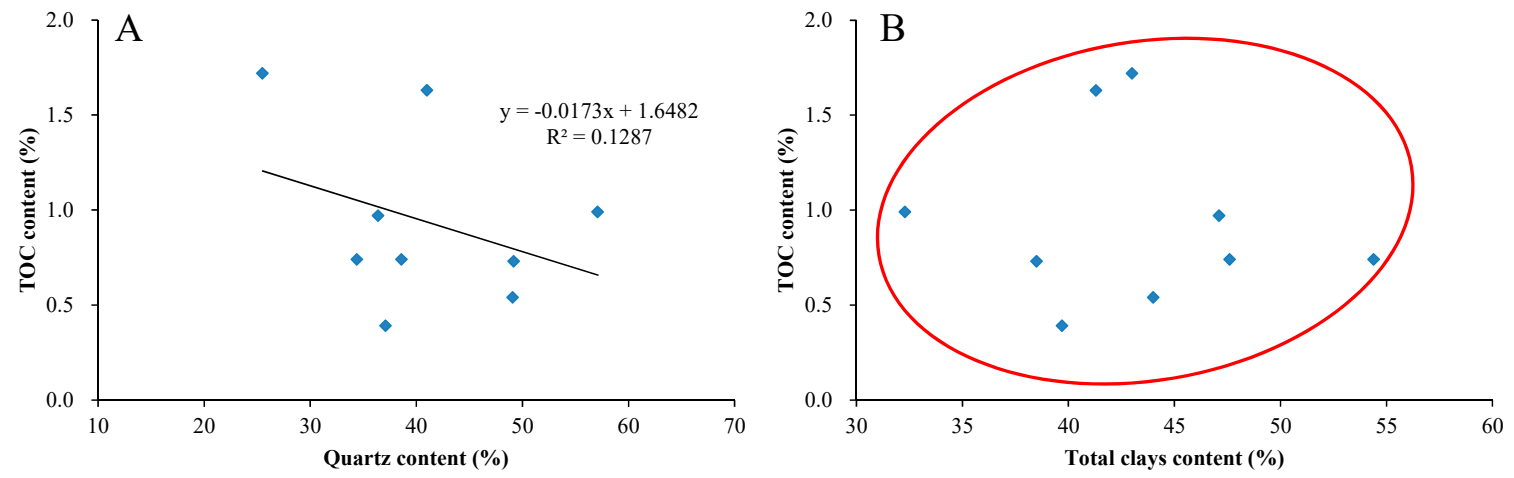

Figure 3. Plots showing the relationships of TOC content with quartz content (A) and total clays content $(\mathbf{B})$ of the shale samples. 


\subsection{Pore Characteristics from FE-SEM Observation}

The FE-SEM images can be used to directly study the occurrence of pores in shale. Loucks et al. divided the pores into interparticle (interP) pores, intraparticle (intraP) pores, and organic-matter (OM) pores [7]. The interP and OM pores in the studied lacustrine shale samples are commonly developed (Figure 4). The OM pores are mainly controlled by the thermal evolution degree and type of organic matter $[15,18,55]$. With the increasing thermal evolution degree, the organic matter is transformed into hydrocarbon, thereby generating $\mathrm{OM}$ pores $[6,18,21,56]$. More specifically, the formation and preservation of $\mathrm{OM}$ pores are closely related to the evolution of kerogen. The evolution process of kerogen can be divided into the following three stages: (1) Diagenesis stage, in which kerogen is gradually formed with loose structure and low degree of polycondensation; (2) Catagenesis stage, in which kerogen begins to degrade, forming hydrocarbons, and its volume shrinks to form OM pores; and (3) Metagenesis stage, in which kerogen further polycondense to form carbon-rich residues, and OM pores gradually collapse or disappear. Such OM pores are mostly spherical or ellipsoidal, and some are honeycomb, mainly with tens to hundreds of nanometers, and usually have good connectivity (Figure 4A,B). In addition, a small number of OM pores are isolated, irregular in shape, and have a complex internal structure, mainly ranging from hundreds of nanometers to several micrometers. As shown in Figure 4C, the organic matter particles are large-sized, but only a few isolated OM pores are developed. Hu et al. and Yang et al. observed the same phenomenon when studying the Lower Silurian Longmaxi shale in the Sichuan Basin, China [36,44]. Curtis et al. pointed out that the reason for the different development of OM pores in organic matter particles which have undergone the same thermal evolution history is the difference in the type and composition of kerogen [18].

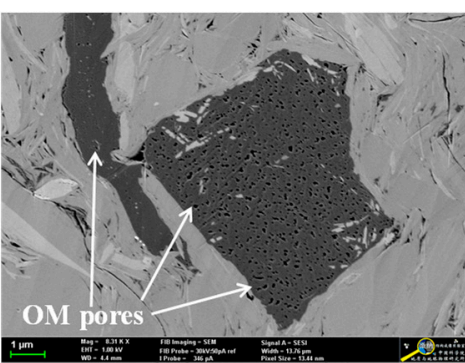

A

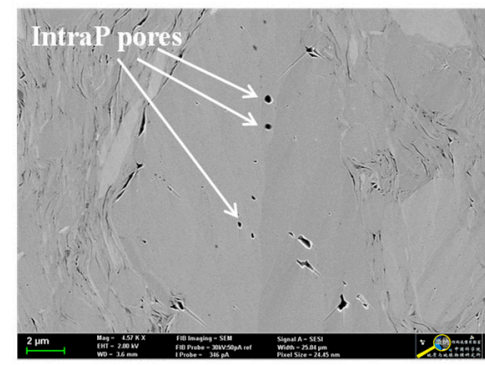

D

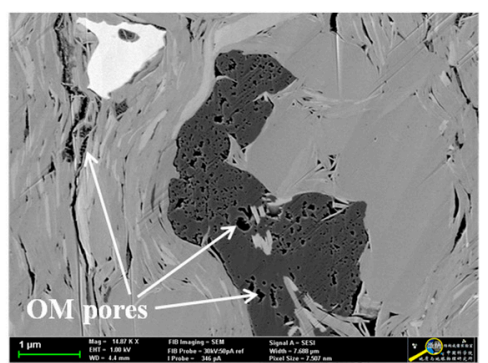

B

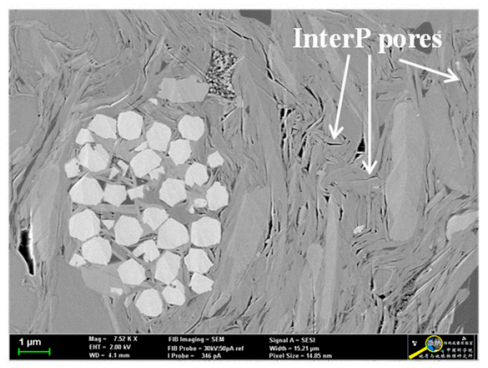

E

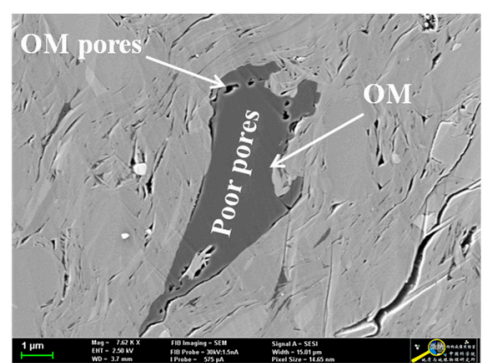

C

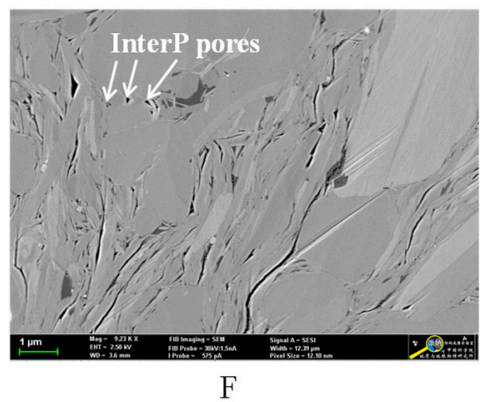

Figure 4. Field emission scanning electron microscopy (FE-SEM) images of micro-nanometer scale pores of the shale samples: (A,B) Abundant OM pores, (C) Heterogeneous OM pores characteristics in the same OM particle, (D) Abundant intraP pores, (E) Abundant interP pores between the clay minerals particles, (F) Abundant interP pores between the brittle minerals particles.

The main kerogen type in the studied shale samples is type III [49] and the thermal weightlessness in the thermal evolution process is lower than that in type I and type II kerogens, therefore, fewer OM pores are formed in the process of thermal evolution hydrocarbon generation. In addition, the maceral groups of type III kerogen are mainly vitrinite and inertinite, and the inertinite group has poor hydrocarbon generation potential, which also greatly inhibits the development of OM pores. 
The interP and intraP pores are mainly developed in the mineral matrix (Figure 4D-F). Such pores are mainly controlled by diagenesis such as compaction, dissolution, and phase transformation of mineral [7]. Due to its strong plasticity, clay minerals are susceptible to compaction and bending deformation. Thus, the formed interP pores are mostly slit-shaped, polygonal, and strip-shaped (Figure 4E). The pores between the brittle minerals particles are mostly angular and mutually connected, which facilitates the migration and flow of shale gas (Figure 4F). The brittle minerals, clay minerals, and organic matters can form long and narrowly curved pores on the contact region of particles. There are also a certain amount of pores among pyrite crystals, which are mostly filled with organic matter and clay minerals. The FE-SEM observation shows that the development of OM pores in the study area is lower than that of Barrnet shale in North America [57] and Longmaxi shale in the southern Sichuan Basin, China [8]. Although the pores in clay minerals are relatively developed, they are affected by sedimentary facies change resulted from multi-period lake transgression and regression, as well as geological structure $[47,49]$. As a result, a part of the pores are distorted, damaged, and closed.

\section{3. $\mathrm{N}_{2}$ Adsorption and Desorption Isotherms}

Figure 5 shows the adsorption and desorption isotherms of $\mathrm{N}_{2}$ in shale samples. As illustrated in Figure 5, there is obvious hysteresis when relative pressure is higher than $0.5\left(P / P_{0}>0.5\right)$. Previous studies have already shown that the adsorption hysteresis occurs mainly due to capillary condensation in the mesopores and macropores [15,44,58,59]. According to the Kelvin equation, capillary condensation does not happen when relative pressure is lower than $0.5\left(P / P_{0}<0.5\right)$, in which range the adsorption and desorption curves overlap on each other [60]. As shown in Figure 5, the shapes of hysteresis loops vary with different shale samples, due to the different pore size distribution and pore geometries associated with shale samples. The discrepancies among these adsorption isotherms under different relative pressures reveal that the adsorption mechanisms are not the same. At lower relative pressures, gas adsorption mainly occurs in the micropores (less than $2 \mathrm{~nm}$ ), where the interaction between gas molecules and shale pore surface molecules is strong, and dominated by Van der Waals force [61]. At higher relative pressures, more gas molecules have access to the mesopores (between 2 and $50 \mathrm{~nm}$ ) and macropores (greater than $50 \mathrm{~nm}$ ), and the interaction among gas molecules acts as the dominant force. As a result, gas adsorption predominantly relies on capillary condensation action [61]. Therefore, it is necessary to investigate the pore surface and structure characteristics of shale to understand their effects on gas adsorption in different pressure regions. 

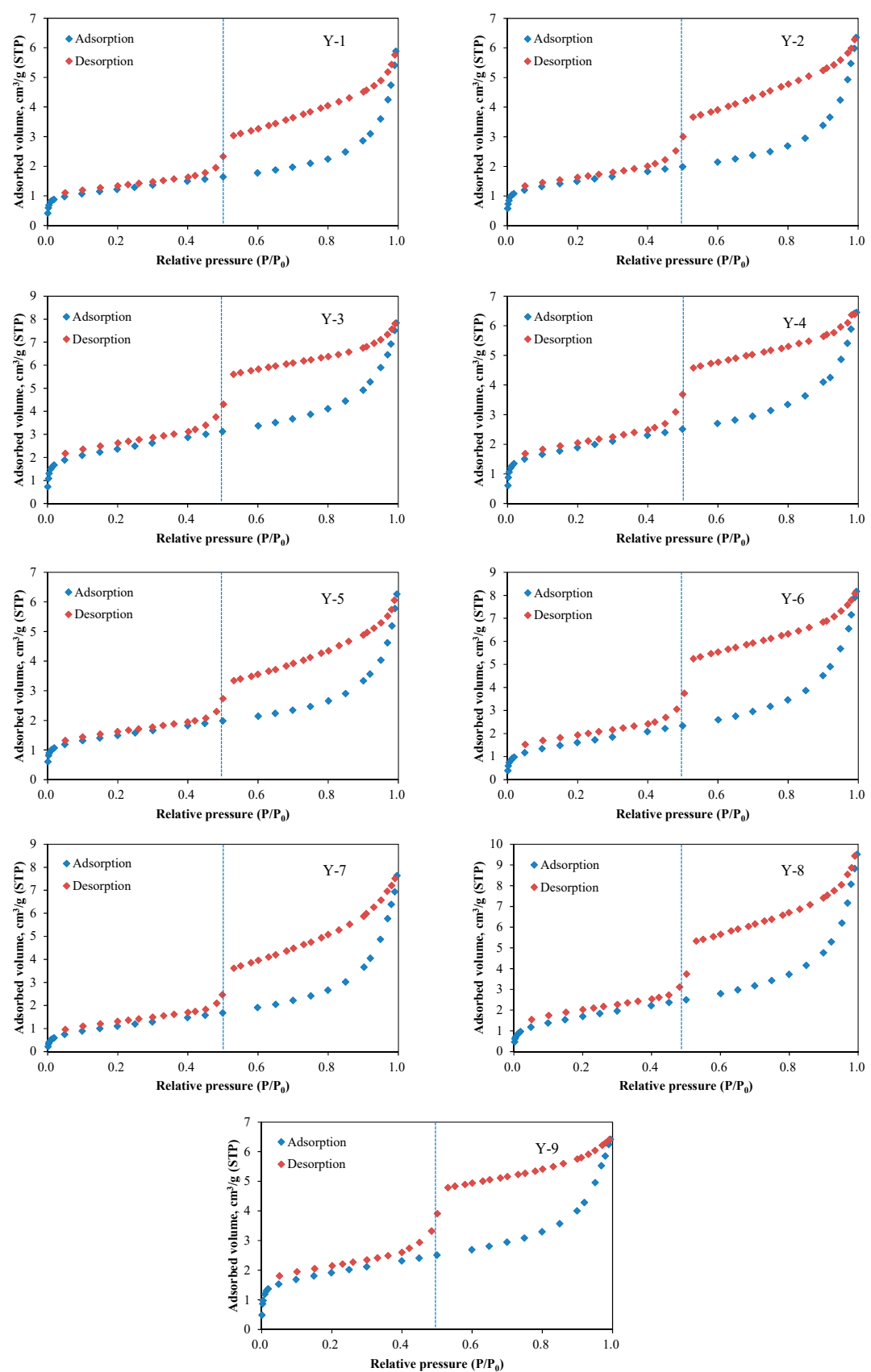

Figure 5. $\mathrm{N}_{2}$ adsorption and desorption isotherms of the shale samples: Y-1-Y-9 represent the sample ID.

\subsection{Pore Structure from $\mathrm{N}_{2}$ Adsorption Isotherms}

Pore structure parameters obtained from $\mathrm{N}_{2}$ adsorption isotherms are shown in Table 1. The Brunauer-Emmett-Teller (BET) surface areas of shale samples range from 4.10 to $8.38 \mathrm{~m}^{2} / \mathrm{g}$ with an average of $5.87 \mathrm{~m}^{2} / \mathrm{g}$, much larger than the surface area of conventional sandstone, which is approximately $1 \mathrm{~m}^{2} / \mathrm{g}$ [62]. The specific surface area of shale is larger than sandstone because shale contains more clay minerals and organic matter, while clay minerals and organic matter have larger specific surface area than other minerals. The large specific surface area can provide sufficient adsorption sites for methane, which is beneficial to adsorbed gas storage. Previous studies show that the amount of adsorbed gas in shale accounts for $20 \%$ to $85 \%$ of the total gas content, with an average of about 50\% [63]. According to the density-functional-theory (DFT) model, the pore size distributions (PSDs) of shale samples are shown in Figure 6. It can be seen that the pore size 
distribution curve of shale is complex and there are multiple different peaks, which may be related to the lacustrine sedimentary environment. The average pore diameters of shale samples range from 5.56 to $10.48 \mathrm{~nm}$ with an average of $7.39 \mathrm{~nm}$. According to the International Union of Pure and Applied Chemistry (IUPAC) classification, the average pore diameter of shale falls into the range of mesopore. Furthermore, the shale contains a certain amount of macropores, resulting in a "tailing" phenomenon in the pore size distribution curve. The DFT pore volumes of shale samples range from 0.0076 to $0.0128 \mathrm{~cm}^{3} / \mathrm{g}$ with an average of $0.0098 \mathrm{~cm}^{3} / \mathrm{g}$. Compared with the coal seam pores dominated by adsorbed gas, the pore volume of shale is one order of magnitude higher than that of coal seam, and larger pores are favorable for natural gas flow [61].

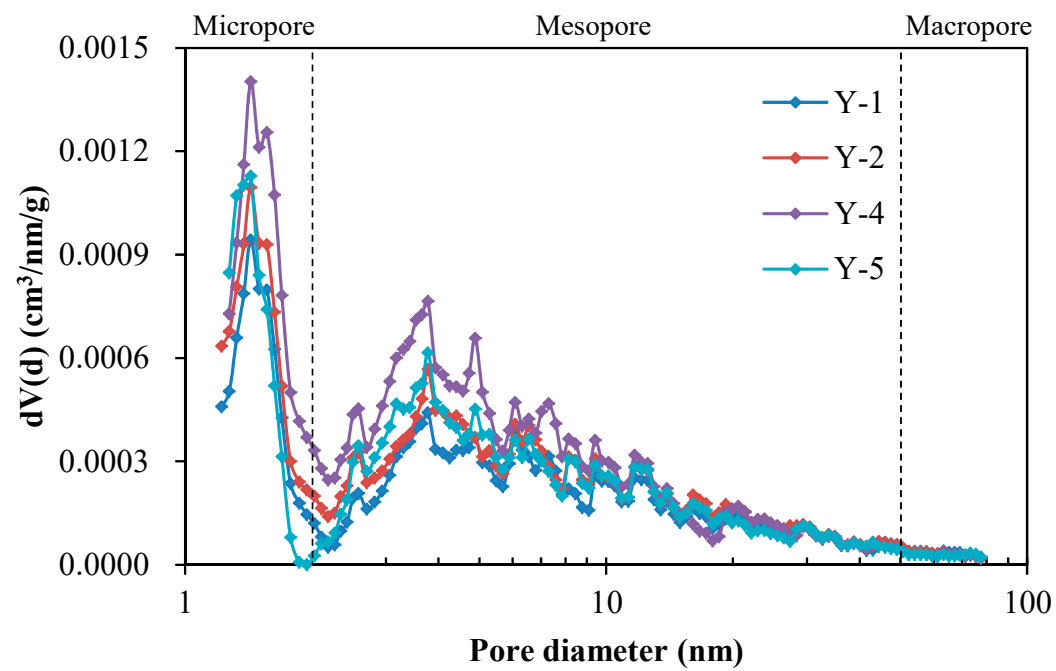

Figure 6. Pore size distributions (PSDs) obtained from $\mathrm{N}_{2}$ adsorption isotherms of four shale samples (Samples Y-1, Y-2, Y-4, and Y-5).

\subsection{Fractal Dimensions from $\mathrm{N}_{2}$ Adsorption Isotherms}

Fractal concept was first proposed in 1975, by Mandelbrot [42], and widely used in porous media including shale [35-41,43-45]. Fractal theory is used to describe the roughness of pore surface and the complexity of pore structure for porous media. It has been developed to be a powerful tool to analyze the geometric and structural characteristics of shale surfaces and pores. The commonly used parameter is fractal dimension $\mathrm{D}$. The larger the fractal dimension, the rougher the pore surface or the more complex the pore structure. It is a well-accepted method to use gas adsorption for fractal dimension calculation [35-41,64]. According to Pfeifer's theory [65], the fractal dimension can be calculated by the FHH equation:

$$
\ln V=K \ln \left[\ln \left(\frac{P_{0}}{P}\right)\right]+C
$$

Where $V$ represents the adsorbed volume $\left(\mathrm{cm}^{3}\right)$ at equilibrium pressure $P(\mathrm{MPa}) ; P_{0}(\mathrm{MPa})$ is the vapor saturation pressure; $K$ is the constant related to adsorption mechanism and fractal dimension $D$; $C$ is a constant.

The relationship between $K$ and $D$ is:

$$
K=D-3 .
$$

As discussed previously, $\mathrm{N}_{2}$ adsorption isotherm overlaps with desorption isotherm when relative pressure is lower than $0.5\left(P / P_{0}<0.5\right)$, the adsorption hysteresis occurs when relative pressure is higher than $0.5\left(P / P_{0}>0.5\right)$, indicating that the adsorption mechanisms before and after this relative pressure $\left(P / P_{0}=0.5\right)$ are different. Therefore, $\mathrm{N}_{2}$ adsorption and desorption isotherms in different pressure regions reflect different characteristics of shale. When calculating the fractal dimension with 
$\mathrm{N}_{2}$ adsorption data, it is necessary to calculate two fractal dimensions at relative pressures of $0-0.5$ and $0.5-1$, respectively, to characterize different characteristics of shale. Therefore, the fractal dimension calculation should be carried out separately at different pressures. In calculating the fractal dimension, regression of adsorption isotherms at low- and high-pressure segments were carried out separately, and two fractal dimension parameters $\mathrm{D}_{1}$ and $\mathrm{D}_{2}$ were generated accordingly. The results of linear regressions are shown in Figure 7 and Table 2. $D_{1}$ values range from 2.2209 to 2.5648, which are generally lower than $\mathrm{D}_{2}$ values that are from 2.6861 to 2.7964 . Previous studies illustrate that $\mathrm{D}_{1}$ and $\mathrm{D}_{2}$ represent two different fractal dimensions of shale [37-39]. $\mathrm{D}_{1}$ mainly represents the pore surface fractal dimension and is used to characterize the roughness of pore surface, however, $\mathrm{D}_{2}$ mainly represents the pore structure fractal dimension and is used to characterize the complexity of pore structure.
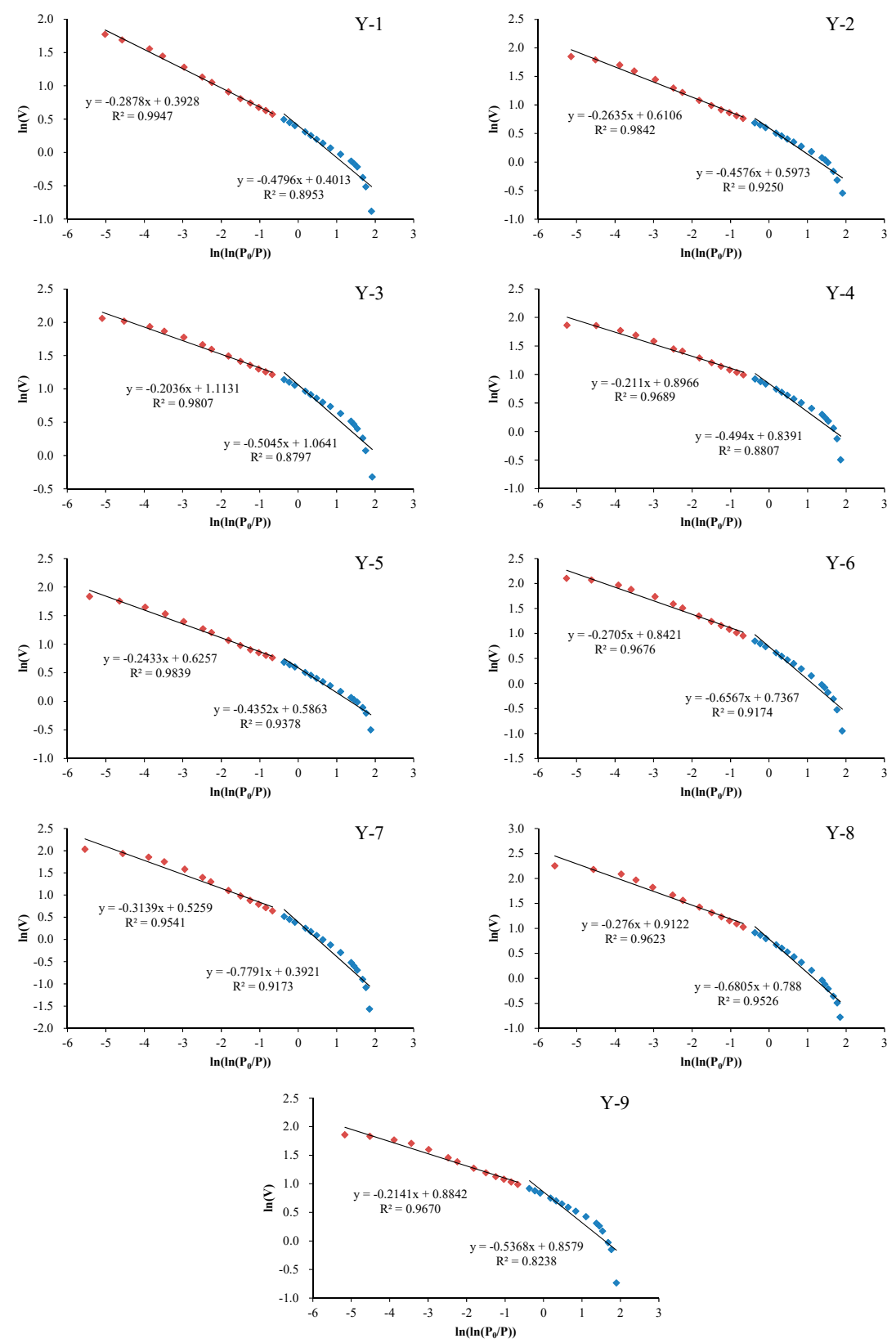

Figure 7. Plots of $\ln (\mathrm{V})$ vs $\ln \left(\ln \left(P_{0} / P\right)\right)$ reconstructed from $\mathrm{N}_{2}$ adsorption isotherms of the shale samples: Y-1-Y-9 represent the sample ID. 
Table 2. Fractal dimensions derived from the Frenkel-Halsey-Hill (FHH) model.

\begin{tabular}{ccccccc}
\hline \multirow{2}{*}{ Sample ID } & \multicolumn{3}{c}{$\mathbf{P} / \mathbf{P}_{\mathbf{0}} \mathbf{0} \mathbf{0 . 5}$} & & \multicolumn{3}{c}{$\mathbf{P}_{\mathbf{0}} \mathbf{0} \mathbf{0 . 5}-\mathbf{1}$} \\
\cline { 2 - 7 } & $\mathbf{K}_{\mathbf{1}}$ & $\mathbf{D}_{\mathbf{1}} \mathbf{=} \mathbf{3}+\mathbf{K}_{\mathbf{1}}$ & $\mathbf{R}^{\mathbf{2}}$ & $\mathbf{K}_{\mathbf{2}}$ & $\mathbf{D}_{\mathbf{2}}=\mathbf{3}+\mathbf{K}_{\mathbf{2}}$ & $\mathbf{R}^{\mathbf{2}}$ \\
\hline Y-1 & -0.4796 & 2.5204 & 0.8953 & -0.2878 & 2.7122 & 0.9947 \\
Y-2 & -0.4576 & 2.5424 & 0.9250 & -0.2635 & 2.7365 & 0.9842 \\
Y-3 & -0.5045 & 2.4955 & 0.8797 & -0.2036 & 2.7964 & 0.9807 \\
Y-4 & -0.4940 & 2.5060 & 0.8807 & -0.2110 & 2.7890 & 0.9689 \\
Y-5 & -0.4352 & 2.5648 & 0.9378 & -0.2433 & 2.7567 & 0.9839 \\
Y-6 & -0.6567 & 2.3433 & 0.9174 & -0.2705 & 2.7295 & 0.9676 \\
Y-7 & -0.7791 & 2.2209 & 0.9173 & -0.3139 & 2.6861 & 0.9541 \\
Y-8 & -0.6805 & 2.3195 & 0.9526 & -0.2760 & 2.7240 & 0.9623 \\
Y-9 & -0.5368 & 2.4632 & 0.8238 & -0.2141 & 2.7859 & 0.9670 \\
\hline
\end{tabular}

\section{Discussion}

\subsection{Specific Surface Area and Pore Volume Characteristics}

Figure 8A shows that there is a significant positive correlation between DFT pore volume and BET surface area of the shale samples in the study area, and both the BET surface area and DFT pore volume have slight negative correlations with average pore diameter (Figure $8 \mathrm{~B}, \mathrm{C}$ ). It should be noted that the decreasing trend of pore volume with the increase of average pore diameter is mainly reflected in the range of average pore diameter less than $8 \mathrm{~nm}$, which may be related to the number distribution of pores with different diameters in the shale samples. Such correlations are similar to the study of lacustrine shale in the Yanchang Formation from the Ordos Basin reported by Jiang et al. [38] and Liu et al. [40]. They pointed out that such correlations indicate that the pore systems of lacustrine shale are mainly dominated by mesopores. As shown in Figure 9, the mesopores are also the main pores of the shale in the study area, providing $52.4 \%$ of total specific surface area and $81.4 \%$ of total pore volume. The micropores contribute $46.8 \%$ of total specific surface area and $9.9 \%$ of total pore volume, while the macropores contribute $0.8 \%$ and $8.7 \%$, respectively. However, the correlations in marine shale are often different from that in lacustrine shale $[66,67]$, which is mainly related to pore types and pore structures in marine and lacustrine shales [68]. The pores in marine shale are mainly derived from a large number of OM pores, while the OM pores mainly falls into the range of micropores. Therefore, they have relatively high specific surface areas and low pore volumes, resulting in the high content of adsorbed gas but low content of free gas in shale. Lacustrine shale not only contains a certain amount of OM nanopores but also a large amount of mineral-associated pores with relatively large pore diameters (Figure 4D-F). The mesopores can not only provide a certain pore volume, but also provide a considerable specific surface area. Therefore, the shale dominated by mesopores has a relatively strong storage capacity for free and adsorbed gas.
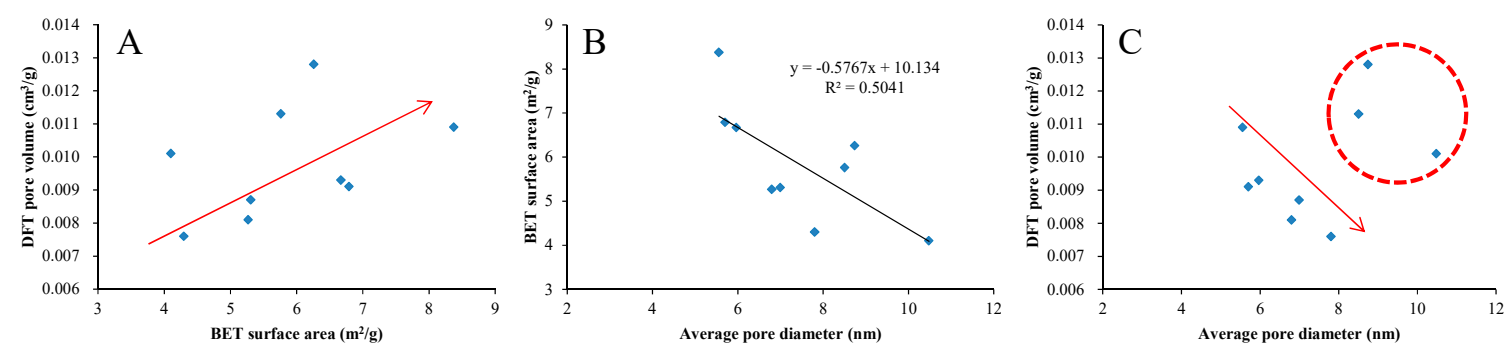

Figure 8. Relationships between density-functional-theory (DFT) pore volume and Brunauer-EmmettTeller (BET) surface area (A), BET surface area and average pore diameter (B), DFT pore volume and average pore diameter $(\mathbf{C})$. 

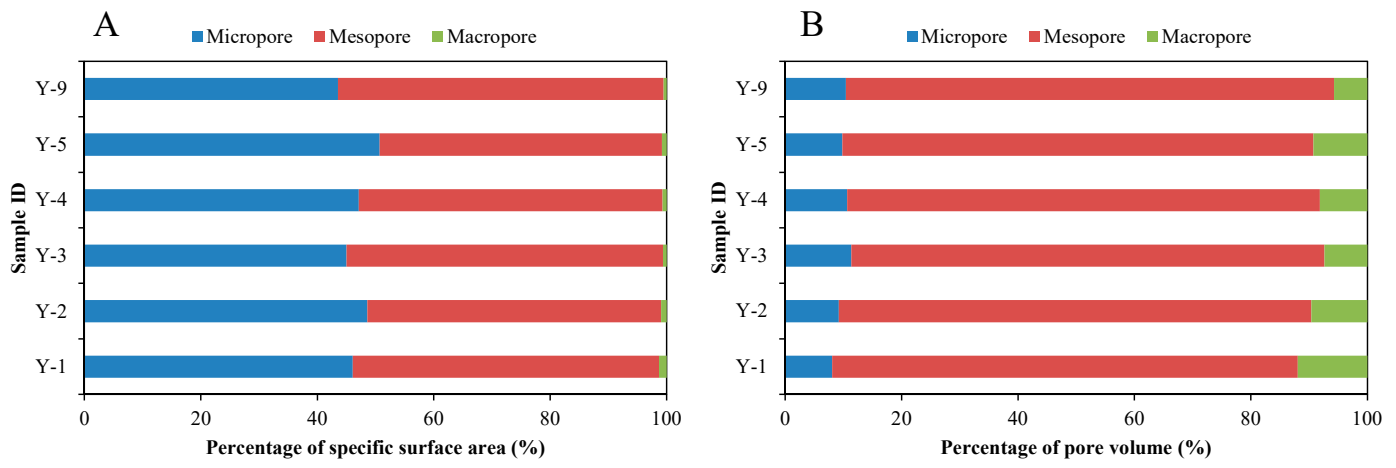

Figure 9. Percentages of specific surface area (A) and pore volume (B) of six typical shale samples.

\subsection{Effects of TOC Content and Mineralogical Composition on Pore Structure}

In order to investigate the controlling factors of pore development from the Lower Jurassic lacustrine shale in the study area, the relationships between pore structure parameters (BET surface area and DFT pore volume) and TOC content and mineralogical composition are plotted in Figure 10. According to the results of XRD analysis, clay minerals and quartz are the most important mineral components of the shale in the study area. Therefore, clay minerals and quartz are mainly discussed in this study. It can be seen that the BET surface area shows no obvious correlation with TOC content, but it is positively correlated with clay minerals content and quartz content (Figure 10A-C). It should be noted that the increasing trend of specific surface area with the increase of quartz content is mainly reflected in the range of quartz content less than $50 \%$, which may be related to the micropores number distribution in quartz of the shale samples. The DFT pore volume is positively correlated with TOC content and clay minerals content, but shows a weak negative correlation with quartz content (Figure 10D-F).
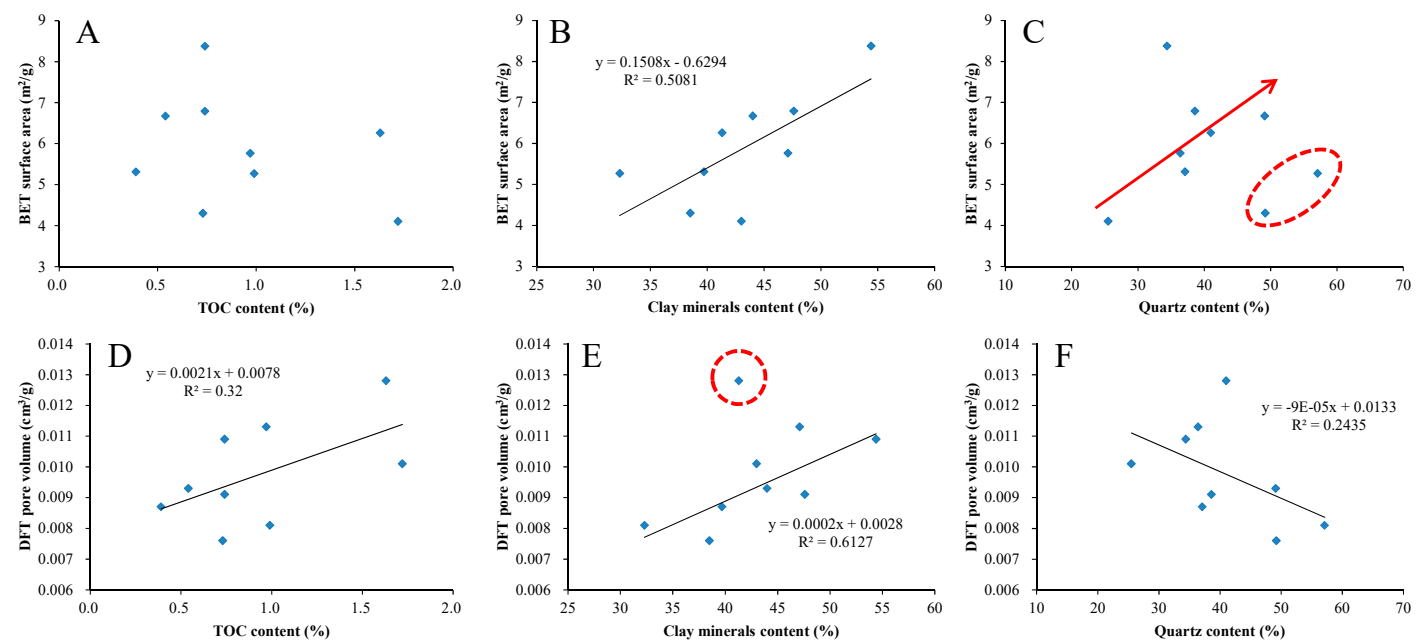

Figure 10. Plots of pore structure parameters (BET surface area and DFT pore volume) versus TOC content (A,D), clay minerals content $(\mathbf{B}, \mathbf{E})$, and quartz content $(\mathbf{C}, \mathbf{F})$.

With the increase of TOC content, the OM pores increase, and the contribution to pore volume of shale also increases, but it has less effect on specific surface area. This may be due to the fact that the pores developed in organic matter of the Lower Jurassic lacustrine shale in the study area are mainly mesopores and macropores, which can also be confirmed by the FE-SEM images (Figure 4A,B). With the increase of clay minerals content, both the specific surface area and pore volume of shale increase, which may be due to the fact that clay minerals not only provide micropores, but also provide mesopores and macropores, which can be confirmed by previous studies [69]. As the quartz content increases, the specific surface area of shale increases, but the pore volume decreases. This may be due 
to the development of a large number of micropores in quartz, whereas the micropores have relatively large specific surface areas but relatively small pore volumes.

The relationships between average pore diameter and TOC content and mineralogical composition are plotted in Figure 11. It can be seen that the average pore diameter has a positive correlation with TOC content (Figure 11A) and a weak negative correlation with quartz content (Figure 11C), but no obvious relationship with clay minerals content (Figure 11B). With the increase of TOC content, large pores (mesopores and macropores) increase in shale, resulting in the increase of average pore diameter. With the increase of quartz content, the increase of micropores in shale leads to a decrease in the average pore diameter, which is also observed in the Lower Silurian Longmaxi shale from the Sichuan Basin, China [43]. However, due to the simultaneous development of small and large pores in clay minerals, the effect on the average pore diameter is not obvious.
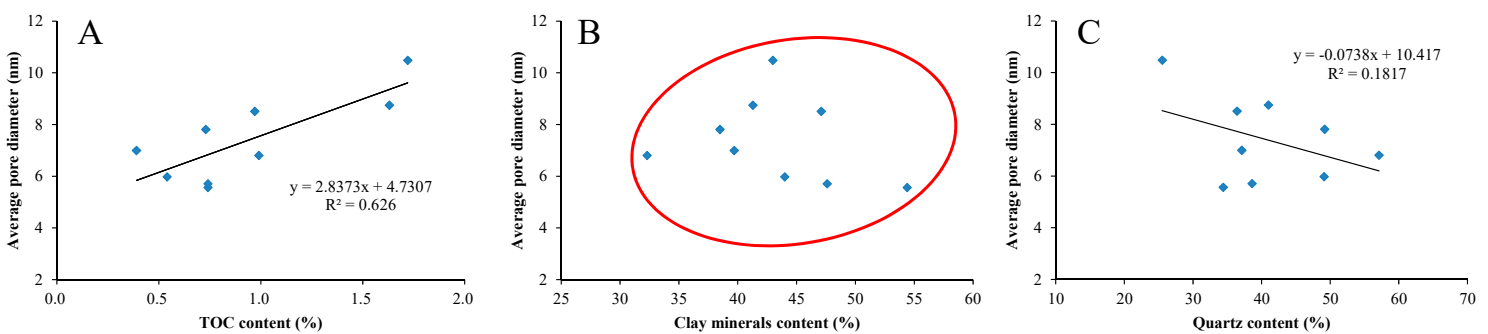

Figure 11. Plots of average pore diameter versus TOC content (A), clay minerals content $(\mathbf{B})$ and quartz content $(\mathbf{C})$.

\subsection{Relationships between Fractal Dimensions and TOC Content and Mineralogical Composition}

Figure 12 shows the relationships between fractal dimensions $\left(D_{1}\right.$ and $\left.D_{2}\right)$ and TOC content and mineralogical composition. The fractal dimension $\mathrm{D}_{1}$ shows a significant negative correlation with TOC content and a significant positive correlation with quartz content, but no obvious correlation with clay minerals content (Figure $12 \mathrm{~A}-\mathrm{C}$ ). The fractal dimension $\mathrm{D}_{2}$ shows a weak negative correlation with TOC content, and a significant positive correlation with clay minerals content and quartz content (Figure 12D-F).
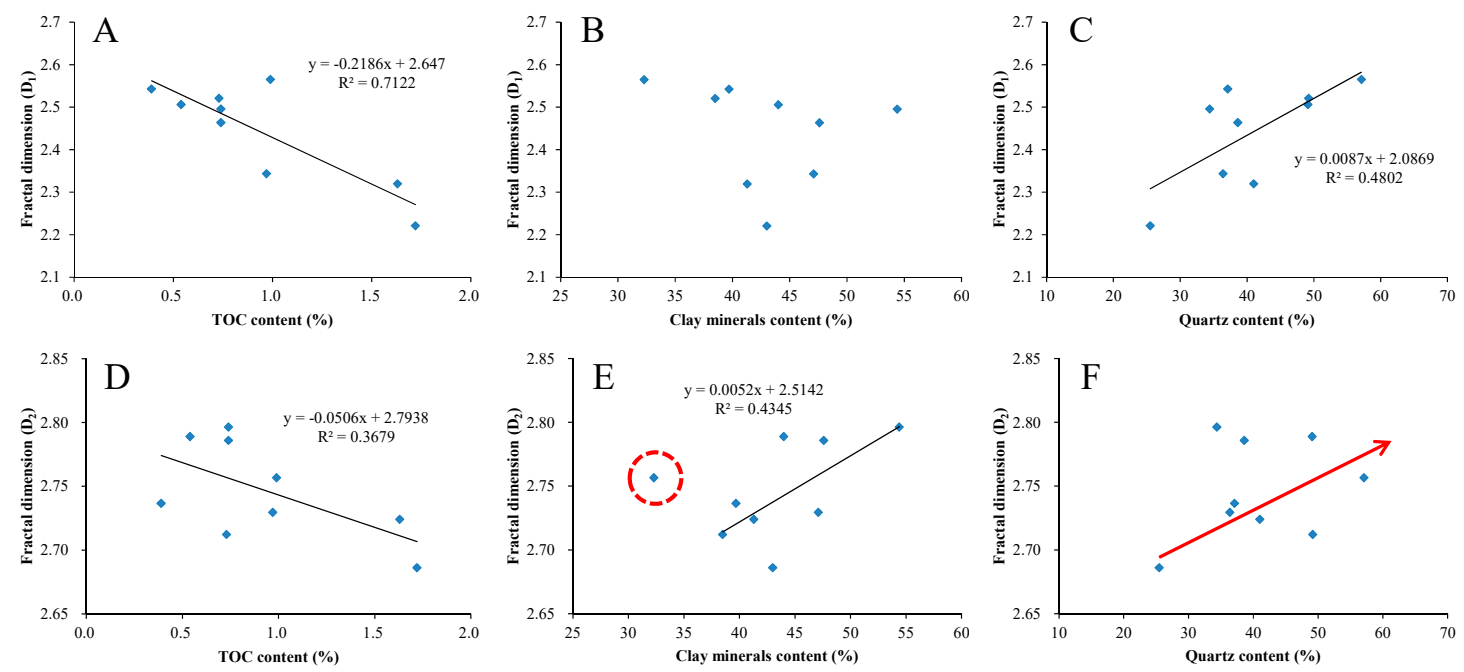

Figure 12. Plots of fractal dimensions $\mathrm{D}_{1}$ and $\mathrm{D}_{2}$ versus TOC content $(\mathbf{A}, \mathbf{D})$, clay minerals content (B,E), and quartz content (C,F).

As previously mentioned, with the increase of TOC content, the number of large pores (mesopores and macropores) in shale increases, resulting in a decrease of pore surface and structure complexity in shale. As a result, both the fractal dimensions $D_{1}$ and $D_{2}$ decrease. This is inconsistent with the 
fact that the fractal dimensions of marine shale increase with the increasing TOC content $[37,43]$. It is mainly because of the high TOC content in marine shale and the development of numerous micropores in organic matter $[15,28,70,71]$, leading to the increase of fractal dimensions of marine shale [37]. With the increase of clay minerals content, the number of micropores in shale increases, leading to a more complex pore structure and a larger fractal dimension $\mathrm{D}_{2}$. Meanwhile, the number of large pores in shale also increases, it can reduce the complexity of pore surface caused by the increase of micropores, resulting in no regular change in fractal dimension $\mathrm{D}_{1}$. With the increase of quartz content, the micropores in shale increase. As a result, the shale pore surface and structure become more complex, thus both the fractal dimensions $\mathrm{D}_{1}$ and $\mathrm{D}_{2}$ increase.

Therefore, it is suggested that clay minerals and quartz are the main controlling factors on the fractal dimensions of the Lower Jurassic lacustrine shale in the study area. In the study of fractal characteristics of marine shale, TOC content and quartz content usually act as the main controlling factors $[37,43]$. This is mainly due to the low content of clay minerals which has little effect on fractal dimension [41]. However, previous studies suggest that clay minerals have an important influence on the pore development of lacustrine shale $[40,72]$. The higher the content of clay minerals, the more developed the pores and the more complex the pore structure. It can be concluded that due to the differences of depositional environments, and the differences of mineralogical composition and organic matter characteristics, the pore development of shale is controlled by different factors.

\subsection{Relationships between Fractal Dimensions and Pore Structure Parameters}

The relationships between fractal dimensions and pore structure parameters (BET surface area, DFT pore volume and average pore diameter) of shale in the study area are illustrated in Figure 13. The fractal dimension $\mathrm{D}_{1}$ has a positive correlation with BET surface area and a negative correlation with DFT pore volume (Figure 13A,B). It should be noted that the increasing trend of fractal dimension $\mathrm{D}_{1}$ with the increase of BET surface area is mainly reflected in the range of BET surface area greater than $6 \mathrm{~m}^{2} / \mathrm{g}$, which may be related to the tortuosity of pore surface in the shale samples. The fractal dimension $\mathrm{D}_{2}$ has a positive correlation with BET surface area and DFT pore volume (Figure 13D,E). It should also be noted that the increasing trend of fractal dimension $\mathrm{D}_{2}$ with the increase of DFT pore volume is mainly reflected in the range of DFT pore volume less than $0.011 \mathrm{~cm}^{3} / \mathrm{g}$, which may be related to the distribution of pore throat in the shale samples. In addition, as shown in Figure 14, there is a good positive correlation between fractal dimension $D_{1}$ and $D_{2}$, which further indicates that $D_{1}$ and $\mathrm{D}_{2}$ can jointly characterize the roughness of pore surface and the complexity of pore structure in shale, and they are not mutually independent. The increase of specific surface area indicates that the number of micropores increases, and the complexity of pore system increases, thus both the fractal dimensions $\mathrm{D}_{1}$ and $\mathrm{D}_{2}$ increase. The increase of pore volume indicates that the number of large pores increases, which reduces the complexity of pore surface and enhances the complexity of pore structure, thus the fractal dimension $\mathrm{D}_{1}$ decreases and $\mathrm{D}_{2}$ increases.

Both the fractal dimensions $\mathrm{D}_{1}$ and $\mathrm{D}_{2}$ decrease with the increase of average pore diameter (Figure $13 \mathrm{C}, \mathrm{F}$ ), but the average pore diameter exerts a greater influence on $\mathrm{D}_{2}$ than $\mathrm{D}_{1}$, suggesting that $\mathrm{D}_{2}$ may be more related to the pore structure fractal dimension, so it is more sensitive to the average pore diameter than $\mathrm{D}_{1}$. Shale samples with smaller average pore diameters may contain more micropores and throats $[37,41,61]$, leading to more complex pore structures and higher fractal dimension $\mathrm{D}_{2}$. These micropores and throats increase the complexity of pore structure, which hinder the diffusion and flow of natural gas in the pore network [37]. 

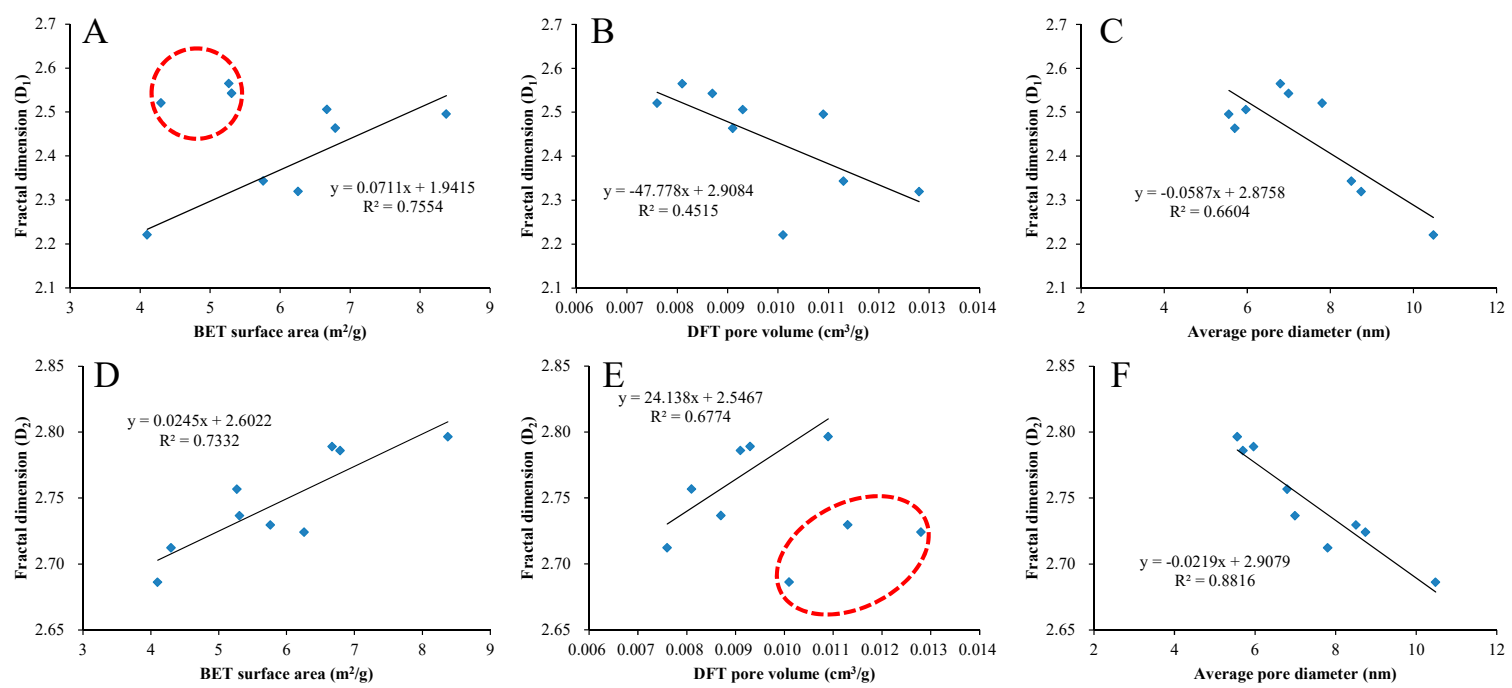

Figure 13. Plots of fractal dimensions $D_{1}$ and $D_{2}$ versus BET surface area $(\mathbf{A}, \mathbf{D})$, DFT pore volume $(\mathbf{B}, \mathbf{E})$, and average pore diameter $(\mathbf{C}, \mathbf{F})$.

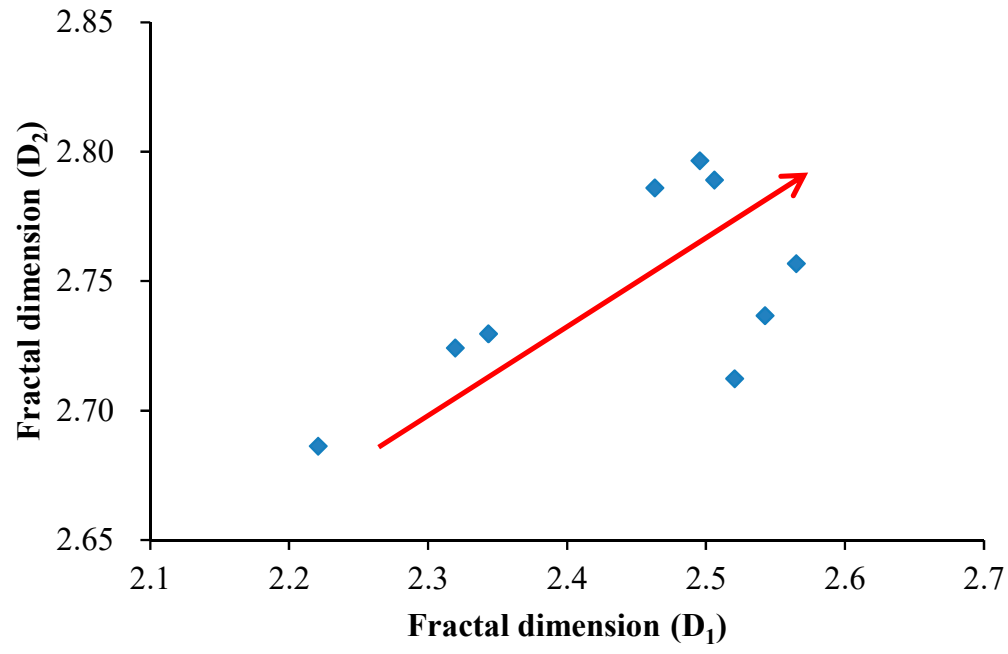

Figure 14. Plot showing the relationship between fractal dimension $D_{1}$ and $D_{2}$.

\subsection{Shale Gas Storage and Production Potential}

Therefore, the adsorbed gas storage capacity of shale would increase with the increase of $D_{1}$ (Figure 15A). However, $\mathrm{D}_{1}$ shows a negative correlation with the pore volume which controls the free gas storage capacity of shale. As a consequence, the free gas storage capacity of shale decreases with the increase of $D_{1}$ (Figure $15 A$ ). Note that the degree of positive correlation between $D_{1}$ and the specific surface area is higher than the degree of negative correlation between $\mathrm{D}_{1}$ and the pore volume, thus the shale gas storage capacity (adsorbed gas storage capacity plus free gas storage capacity) are shown in the order: Region $1<$ Region $2<$ Region 3 (Figure 15A). It is indicated here that Region 1 refers to a region with relatively small $D_{1}$ value (for example, 2.1-2.3), Region 2 refers to a region with relatively moderate $D_{1}$ value (for example, 2.3-2.5), and Region 3 refers to a region with relatively large $\mathrm{D}_{1}$ value (for example, 2.5-2.7).

In addition, the fractal dimension $\mathrm{D}_{2}$ is positively correlated with the specific surface area and pore volume, thus both the absorbed gas and free gas storage capacity of shale would increase when $\mathrm{D}_{2}$ increases (Figure 15B). Therefore, the shale gas storage capacity are shown in the order: Region $4<$ Region $5<$ Region 6 (Figure 15B). It is indicated here that Region 4 refers to a region with relatively small $\mathrm{D}_{2}$ value (for example, 2.65-2.70), Region 5 refers to a region with relatively moderate $\mathrm{D}_{2}$ value (for example, 2.70-2.75), and Region 6 refers to a region with relatively large $\mathrm{D}_{2}$ value (for 
example, 2.75-2.80). However, due to the strong negative relationship between $\mathrm{D}_{2}$ and the average pore diameter, the average pore diameter of shale would decreases with the increase of $\mathrm{D}_{2}$. It will enhance the complexity of pore structure, further hindering the natural gas diffusion and flow in shale (Region 6). In summary, it is suggested that shale with a large $\mathrm{D}_{1}$ (Region 3 ) and a moderate $\mathrm{D}_{2}$ (Region 5) has a strong capacity to store both adsorbed gas and free gas, and it also facilitates the exploitation and production of shale gas.
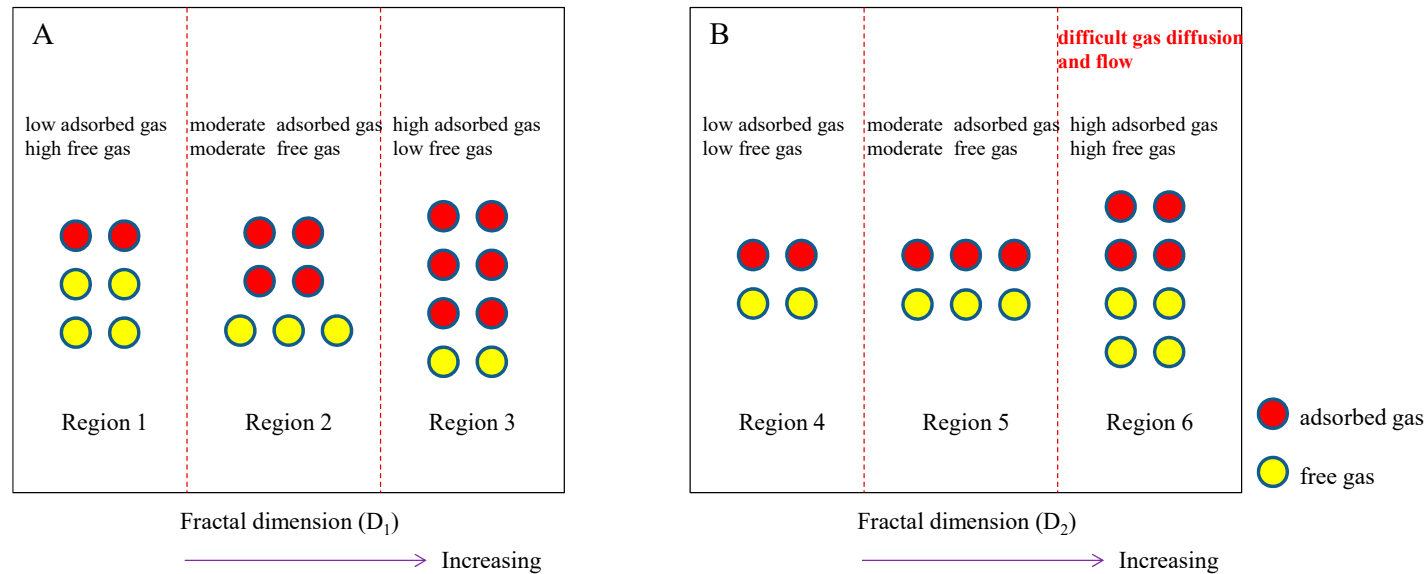

Figure 15. Relationships between shale gas storage capacity and fractal dimensions: $(A) D_{1},(B) D_{2}$.

\section{Conclusions}

In this paper, the pore structure and fractal characteristics of the Lower Jurassic lacustrine shale in the Sichuan Basin, SW China were investigated using a series of experiments and FHH theory. The following are the main conclusions from our study:

(1) Pore types in shale are mainly OM and interP pores, along with a small amount of intraP pores, and that not all grains of OM have the same porosity. The BET surface areas of shale samples range from 4.10 to $8.38 \mathrm{~m}^{2} / \mathrm{g}$ with an average of $5.87 \mathrm{~m}^{2} / \mathrm{g}$, DFT pore volumes range from 0.0076 to $0.0128 \mathrm{~cm}^{3} / \mathrm{g}$ with an average of $0.0098 \mathrm{~cm}^{3} / \mathrm{g}$, and average pore diameters range from 5.56 to $10.48 \mathrm{~nm}$ with an average of $7.39 \mathrm{~nm}$.

(2) $\mathrm{N}_{2}$ adsorption experimental results show that shale has different adsorption characteristics at the relative pressure of $0-0.5$ and $0.5-1$. On this basis, two fractal dimensions $\mathrm{D}_{1}$ and $\mathrm{D}_{2}$ are obtained using $\mathrm{FHH}$ equation, with $\mathrm{D}_{1}$ values ranging from 2.2209 to 2.5648 , and $\mathrm{D}_{2}$ values ranging from 2.6861 to 2.7964 .

(3) The BET surface area shows a positive correlation with clay minerals content and quartz content, but no obvious relationship with TOC content. The DFT pore volume shows a positive correlation with TOC content and clay minerals content, but a negative relationship with quartz content. In addition, the average pore diameter shows a positive correlation with TOC content and a negative relationship with quartz content, but no obvious relationship with clay minerals content.

(4) Fractal dimension $\mathrm{D}_{1}$ is mainly closely associated with the specific surface area of shale, suggesting that $D_{1}$ may represent the pore surface fractal dimension. Whereas fractal dimension $D_{2}$ is sensitive to multiple parameters including the specific surface area, pore volume, and average pore diameter, suggesting that $\mathrm{D}_{2}$ may represent the pore structure fractal dimension.

(5) Shale with a large fractal dimension $D_{1}$ and a moderate fractal dimension $D_{2}$ has a strong capacity to store both adsorbed gas and free gas, and it also facilitates the exploitation and production of shale gas.

Other relevant experiments such as low-pressure $\mathrm{CO}_{2}$ adsorption, high-pressure mercury intrusion porosimetry (MIP), nuclear magnetic resonance (NMR) and nano-computed tomography (nano-CT) need to be further conducted to provide a more comprehensive understanding on pore structure and fractal characteristics of lacustrine shale. 
Author Contributions: Formal analysis, L.C.; Investigation, F.G.; Project administration, Z.J.; Resources, W.Y.; Supervision, J.T.; Writing — original draft, L.C.; Writing—review \& editing, S.J. and K.L.

Funding: This research was funded by the National Science and Technology Major Project of China (No. 2016ZX05034-001) and the National Natural Science Foundation of China (No. 41872135).

Acknowledgments: The authors would like to acknowledge the financial support of the National Science and Technology Major Project of China (No. 2016ZX05034-001) and the National Natural Science Foundation of China (No. 41872135). Special thanks are given to the China Scholarship Council (No. 201706440133) for sponsoring the first author to be a visiting scholar in the University of Utah.

Conflicts of Interest: The authors declare no conflict of interest.

\section{References}

1. Chen, S.B.; Zhu, Y.M.; Wang, H.Y.; Liu, H.L.; Wei, W.; Fang, J.H. Shale gas reservoir characterization: A typical case in the southern Sichuan Basin of China. Energy 2011, 36, 6609-6616. [CrossRef]

2. Chen, L.; Jiang, Z.X.; Liu, K.Y.; Wang, P.F.; Ji, W.M.; Gao, F.L.; Li, P.; Hu, T.; Zhang, B.; Huang, H. Effect of lithofacies on gas storage capacity of marine and continental shales in the Sichuan Basin, China. J. Nat. Gas Sci. Eng. 2016, 36, 773-785. [CrossRef]

3. Jiang, S.; Xu, Z.Y.; Feng, Y.L.; Zhang, J.C.; Cai, D.S.; Chen, L.; Wu, Y.; Zhou, D.; Bao, S.; Long, S. Geologic characteristics of hydrocarbon-bearing marine, transitional and lacustrine shales in China. J. Asian Earth Sci. 2016, 115, 404-418. [CrossRef]

4. Huang, H.X.; Sun, W.; Xiong, F.Y.; Chen, L.; Li, X.; Gao, T.; Jiang, Z.; Ji, W.; Wu, Y.; Han, J. A novel method to estimate subsurface shale gas capacities. Fuel 2018, 232, 341-350. [CrossRef]

5. Wang, X.; He, S.; Guo, X.W.; Zhang, B.Q.; Chen, X.H. The resource evaluation of Jurassic shale in North Fuling area, eastern Sichuan Basin, China. Energy Fuels 2018, 32, 1213-1222. [CrossRef]

6. Loucks, R.G.; Reed, R.M.; Ruppel, S.C.; Jarvie, D.M. Morphology, genesis, and distribution of nanometer-scale pores in siliceous mudstones of the Mississippian Barnett shale. J. Sediment. Res. 2009, 79, 848-861. [CrossRef]

7. Loucks, R.G.; Reed, R.M.; Ruppel, S.C.; Hammes, U. Spectrum of pore types and networks in mudrocks and a descriptive classification for matrix-related mudrock pores. AAPG Bull. 2012, 96, 1071-1098. [CrossRef]

8. Zhang, L.C.; Li, B.; Jiang, S.; Xiao, D.S.; Lu, S.F.; Zhang, Y.Y.; Gong, C.; Chen, L. Heterogeneity characterization of the lower Silurian Longmaxi marine shale in the Pengshui area, South China. Int. J. Coal Geol. 2018, 195, 250-266. [CrossRef]

9. Chen, L.; Jiang, Z.X.; Liu, K.Y.; Gao, F.L.; Wang, P.F. A combination of $\mathrm{N}_{2}$ and $\mathrm{CO}_{2}$ adsorption to characterize nanopore structure of organic-rich Lower Silurian shale in the Upper Yangtze Platform, South China: Implications for shale gas sorption capacity. Acta Geol. Sin. (Engl. Ed.) 2017, 91, 1380-1394. [CrossRef]

10. Tan, J.Q.; Weniger, P.; Krooss, B.; Merkel, A.; Horsfield, B.; Zhang, J.C.; Boreham, C.J.; Graas, G.v.; Tocher, B.A. Shale gas potential of the major marine shale formations in the Upper Yangtze Platform, South China, Part II: Methane sorption capacity. Fuel 2014, 129, 204-218. [CrossRef]

11. Xiong, F.Y.; Jiang, Z.X.; Li, P.; Wang, X.Z.; Bi, H.; Li, Y.R.; Wang, Z.Y.; Amooie, M.A.; Soltanian, M.R.; Moortgat, J. Pore structure of transitional shales in the Ordos Basin, NW China: Effects of composition on gas storage capacity. Fuel 2017, 206, 504-515. [CrossRef]

12. Chen, L.; Zuo, L.; Jiang, Z.X.; Jiang, S.; Liu, K.Y.; Tan, J.Q.; Zhang, L. Mechanisms of shale gas adsorption: Evidence from thermodynamics and kinetics study of methane adsorption on shale. Chem. Eng. J. 2019, 361, 559-570. [CrossRef]

13. Bakshi, T.; Prusty, B.K.; Pathak, K.; Pal, S.K. Pore characteristics of Damodar valley shale and their effect on gas storage potential. J. Pet. Sci. Eng. 2018, 162, 725-735. [CrossRef]

14. He, J.L.; Wang, J.; Yu, Q.; Liu, W.; Ge, X.Y.; Yang, P.; Wang, Z.; Lu, J. Pore structure of shale and its effects on gas storage and transmission capacity in well HD-1 eastern Sichuan Basin, China. Fuel 2018, 226, 709-720. [CrossRef]

15. Chen, L.; Jiang, Z.X.; Liu, K.Y.; Tan, J.Q.; Gao, F.L.; Wang, P.F. Pore structure characterization for organic-rich Lower Silurian shale in the Upper Yangtze Platform, South China: A possible mechanism for pore development. J. Nat. Gas Sci. Eng. 2017, 46, 1-15. [CrossRef] 
16. Clarkson, C.R.; Solano, N.; Bustin, R.M.; Bustin, A.M.M.; Chalmers, G.R.L.; He, L.; Melnichenko, Y.B.; Radliński, A.P.; Blach, T.P. Pore structure characterization of North American shale gas reservoirs using USANS/SANS, gas adsorption, and mercury intrusion. Fuel 2013, 103, 606-616. [CrossRef]

17. Curtis, M.E.; Sondergeld, C.H.; Ambrose, R.J.; Rai, C.S. Microstructural investigation of gas shales in two and three dimensions using nanometer-scale resolution imaging. AAPG Bull. 2012, 96, 665-677. [CrossRef]

18. Curtis, M.E.; Cardott, B.J.; Sondergeld, C.H.; Rai, C.S. Development of organic porosity in the Woodford Shale with increasing thermal maturity. Int. J. Coal Geol. 2012, 103, 26-31. [CrossRef]

19. Klaver, J.; Desbois, G.; Little, R.; Urai, J.L. BIB-SEM characterization of pore space morphology and distribution in postmature to overmature samples from the Haynesville and Bossier Shales. Mar. Pet. Geol. 2015, 59, 451-466. [CrossRef]

20. Klaver, J.; Desbois, G.; Little, R.; Urai, J.L. BIB-SEM pore characterization of mature and post mature Posidonia Shale samples from the Hils area, Germany. Int. J. Coal Geol. 2016, 158, 78-89. [CrossRef]

21. Bernard, S.; Horsfield, B.; Schulz, H.M.; Wirth, R.; Schreiber, A.; Sherwood, N. Geochemical evolution of organic-rich shales with increasing maturity: A STXM and TEM study of the Posidonia Shale (Lower Toarcian, northern Germany). Mar. Pet. Geol. 2012, 31, 70-89. [CrossRef]

22. Chalmers, G.R.; Bustin, R.M.; Power, I.M. Characterization of gas shale pore systems by porosimetry, pycnometry, surface area, and field emission scanning electron microscopy/transmission electron microscopy image analyses: Examples from the Barnett, Woodford, Haynesville, Marcellus, and Doig units. AAPG Bull. 2012, 96, 1099-1119.

23. Gu, X.; Cole, D.R.; Rother, G.; Mildner, D.F.R.; Brantley, S.L. Pores in Marcellus shale: A neutron scattering and FIB-SEM study. Energy Fuels 2015, 29, 1295-1308. [CrossRef]

24. Jiang, F.J.; Chen, J.; Xu, Z.Y.; Wang, Z.F.; Hu, T.; Chen, D.; Li, Q.; Li, Y. Organic matter pore characterization in lacustrine shales with variable maturity using nanometer-scale resolution $X$-ray computed tomography. Energy Fuels 2017, 31, 2669-2680. [CrossRef]

25. Wang, P.F.; Jiang, Z.X.; Chen, L.; Yin, L.S.; Li, Z.; Zhang, C.; Tang, X.; Wang, G. Pore structure characterization for the Longmaxi and Niutitang shales in the Upper Yangtze Platform, South China: Evidence from focused ion beam-He ion microscopy, nano-computerized tomography and gas adsorption analysis. Mar. Pet. Geol. 2016, 77, 1323-1337. [CrossRef]

26. Zhou, S.W.; Yan, G.; Xue, H.Q.; Guo, W.; Li, X.B. 2D and 3D nanopore characterization of gas shale in Longmaxi formation based on FIB-SEM. Mar. Pet. Geol. 2016, 73, 174-180. [CrossRef]

27. Zhang, L.; Xiong, Y.Q.; Li, Y.; Wei, M.M.; Jiang, W.M.; Lei, R.; Wu, Z. DFT modeling of $\mathrm{CO}_{2}$ and $\mathrm{Ar}$ low-pressure adsorption for accurate nanopore structure characterization in organic-rich shales. Fuel 2017, 204, 1-11. [CrossRef]

28. Tian, H.; Pan, L.; Zhang, T.W.; Xiao, X.M.; Meng, Z.P.; Huang, B.J. Pore characterization of organic-rich Lower Cambrian shales in Qiannan Depression of Guizhou Province, Southwestern China. Mar. Pet. Geol. 2015, 62, 28-43. [CrossRef]

29. Chen, L.; Jiang, Z.X.; Liu, K.Y.; Wang, P.F.; Gao, F.L.; Hu, T. Application of low-pressure gas adsorption to nanopore structure characterisation of organic-rich Lower Cambrian shale in the Upper Yangtze Platform, South China. Aust. J. Earth Sci. 2017, 64, 653-665. [CrossRef]

30. Labani, M.M.; Rezaee, R.; Saeedi, A.; Hinai, A.A. Evaluation of pore size spectrum of gas shale reservoirs using low pressure nitrogen adsorption, gas expansion and mercury porosimetry: A case study from the Perth and Canning Basins, Western Australia. J. Pet. Sci. Eng. 2013, 112, 7-16. [CrossRef]

31. Li, Z.Q.; Qi, Z.Y.; Shen, X.; Hu, R.L.; Huang, R.Q.; Han, Q. Research on quantitative analysis for nanopore structure characteristics of shale based on NMR and NMR cryoporometry. Energy Fuels 2017, 31, 5844-5853. [CrossRef]

32. Mastalerz, M.; He, L.L.; Melnichenko, Y.B.; Rupp, J.A. Porosity of coal and shale: Insights from gas adsorption and SANS/USANS techniques. Energy Fuels 2012, 26, 5109-5120. [CrossRef]

33. Mastalerz, M.; Schimmelmann, A.; Drobniak, A.; Chen, Y.Y. Porosity of Devonian and Mississippian New Albany Shale across a maturation gradient: Insights from organic petrology, gas adsorption, and mercury intrusion. AAPG Bull. 2013, 97, 1621-1643. [CrossRef]

34. Bahadur, J.; Ruppert, L.F.; Pipich, V.; Sakurovs, R.; Melnichenko, Y.B. Porosity of the Marcellus Shale: A contrast matching small-angle neutron scattering study. Int. J. Coal Geol. 2018, 188, 156-164. [CrossRef] 
35. Chen, L.; Jiang, Z.X.; Liu, K.Y.; Yang, W.; Jiang, S.; Tan, J.Q. Investigation of fractal characteristics and methane adsorption capacity of the Upper Triassic lacustrine shale in the Sichuan Basin, southwest China. Fractals 2019, 27. [CrossRef]

36. Hu, J.G.; Tang, S.H.; Zhang, S.H. Investigation of pore structure and fractal characteristics of the Lower Silurian Longmaxi shales in western Hunan and Hubei Provinces in China. J. Nat. Gas Sci. Eng. 2016, 28, 522-535. [CrossRef]

37. Ji, W.M.; Song, Y.; Jiang, Z.X.; Meng, M.M.; Liu, Q.X.; Chen, L.; Wang, P.; Gao, F.; Huang, H. Fractal characteristics of nano-pores in the Lower Silurian Longmaxi shales from the Upper Yangtze Platform, south China. Mar. Pet. Geol. 2016, 78, 88-98. [CrossRef]

38. Jiang, F.J.; Chen, D.; Chen, J.; Li, Q.W.; Liu, Y.; Shao, X.H.; Hu, T.; Dai, J.X. Fractal analysis of shale pore structure of continental gas shale reservoir in the Ordos Basin, NW China. Energy Fuels 2016, 30, 4676-4689. [CrossRef]

39. Li, A.; Ding, W.L.; He, J.H.; Dai, P.; Yin, S.; Xie, F. Investigation of pore structure and fractal characteristics of organic-rich shale reservoirs: A case study of Lower Cambrian Qiongzhusi formation in Malong block of eastern Yunnan Province, South China. Mar. Pet. Geol. 2016, 70, 46-57. [CrossRef]

40. Liu, X.J.; Xiong, J.; Liang, L.X. Investigation of pore structure and fractal characteristics of organic-rich Yanchang formation shale in central China by nitrogen adsorption/desorption analysis. J. Nat. Gas Sci. Eng. 2015, 22, 62-72. [CrossRef]

41. Yang, F.; Ning, Z.F.; Liu, H.Q. Fractal characteristics of shales from a shale gas reservoir in the Sichuan Basin, China. Fuel 2014, 115, 378-384. [CrossRef]

42. Mandelbrot, B.B. Stochastic models for the Earth's relief, the shape and the fractal dimension of the coastlines, and the number-area rule for islands. Proc. Natl. Acad. Sci. USA 1975, 72, 3825-3828. [CrossRef] [PubMed]

43. Shao, X.H.; Pang, X.Q.; Li, Q.W.; Wang, P.W.; Chen, D.; Shen, W.B.; Zhao, Z. Pore structure and fractal characteristics of organic-rich shales: A case study of the lower Silurian Longmaxi shales in the Sichuan Basin, SW China. Mar. Pet. Geol. 2017, 80, 192-202. [CrossRef]

44. Yang, R.; He, S.; Yi, J.Z.; Hu, Q.H. Nano-scale pore structure and fractal dimension of organic-rich Wufeng-Longmaxi shale from Jiaoshiba area, Sichuan Basin: Investigations using FE-SEM, gas adsorption and helium pycnometry. Mar. Pet. Geol. 2016, 70, 27-45. [CrossRef]

45. Yang, C.; Zhang, J.C.; Wang, X.Z.; Tang, X.; Chen, Y.C.; Jiang, L.L.; Gong, X. Nanoscale pore structure and fractal characteristics of a marine-continental transitional shale: A case study from the lower Permian Shanxi Shale in the southeastern Ordos Basin, China. Mar. Pet. Geol. 2017, 88, 54-68. [CrossRef]

46. Jiang, S.; Tang, X.L.; Cai, D.S.; Xue, G.; He, Z.L.; Long, S.X.; Peng, Y.; Gao, B.; Xu, Z.; Dahdah, N. Comparison of marine, transitional, and lacustrine shales: A case study from the Sichuan Basin in China. J. Pet. Sci. Eng. 2017, 150, 334-347. [CrossRef]

47. Xu, Q.L.; Liu, B.; Ma, Y.S.; Song, X.M.; Wang, Y.J.; Xin, X.K.; Chen, Z.X. Controlling factors and dynamical formation models of lacustrine organic matter accumulation for the Jurassic Da'anzhai Member in the central Sichuan Basin, southwestern China. Mar. Pet. Geol. 2017, 86, 1391-1405. [CrossRef]

48. Ma, Y.S.; Guo, X.S.; Guo, T.L.; Huang, R.; Cai, X.Y.; Li, G.X. The Puguang gas field: New giant discovery in the mature Sichuan Basin, southwest China. AAPG Bull. 2007, 91, 627-643. [CrossRef]

49. Xu, Q.L.; Liu, B.; Ma, Y.S.; Song, X.M.; Wang, Y.J.; Chen, Z.X. Geological and geochemical characterization of lacustrine shale: A case study of the Jurassic Da'anzhai member shale in the central Sichuan Basin, southwest China. Proc. Natl. Acad. Sci. USA 2017, 47, 124-139. [CrossRef]

50. Mastalerz, M.; Hampton, L.; Drobniak, A.; Loope, H. Significance of analytical particle size in low-pressure $\mathrm{N}_{2}$ and $\mathrm{CO}_{2}$ adsorption of coal and shale. Int. J. Coal Geol. 2017, 178, 122-131. [CrossRef]

51. Chalmers, G.R.L.; Ross, D.J.K.; Bustin, R.M. Geological controls on matrix permeability of Devonian Gas Shales in the Horn River and Liard basins, northeastern British Columbia, Canada. Int. J. Coal Geol. 2012, 103, 120-131. [CrossRef]

52. Yang, R.; He, S.; Hu, Q.H.; Hu, D.F.; Zhang, S.W.; Yi, J.Z. Pore characterization and methane sorption capacity of over-mature organic-rich Wufeng and Longmaxi shales in the southeast Sichuan Basin, China. Mar. Pet. Geol. 2016, 77, 247-261. [CrossRef]

53. Dong, T.; Harris, N.B.; Ayranci, K.; Twemlow, C.E.; Nassichuk, B.R. Porosity characteristics of the Devonian Horn River shale, Canada: Insights from lithofacies classification and shale composition. Int. J. Coal Geol. 2015, 141, 74-90. [CrossRef] 
54. Li, P.P.; Hao, F.; Guo, X.S.; Zou, H.Y.; Yu, X.Y.; Wang, G.W. Processes involved in the origin and accumulation of hydrocarbon gases in the Yuanba gas field, Sichuan Basin, southwest China. Mar. Pet. Geol. 2015, 59, 150-165. [CrossRef]

55. Furmann, A.; Mastalerz, M.; Schimmelmann, A.; Pedersen, P.K.; Bish, D. Relationships between porosity, organic matter, and mineral matter in mature organic-rich marine mudstones of the Belle Fourche and Second White Specks formations in Alberta, Canada. Mar. Pet. Geol. 2014, 54, 65-81. [CrossRef]

56. Jarvie, D.M.; Hill, R.J.; Ruble, T.E.; Pollastro, R.M. Unconventional shale-gas systems: The Mississippian Barnett Shale of north-central Texas as one model for thermogenic shale-gas assessment. AAPG Bull. 2007, 91, 475-499. [CrossRef]

57. Ko, L.T.; Ruppel, S.C.; Loucks, R.G.; Hackley, P.C.; Zhang, T.W.; Shao, D.Y. Pore-types and pore-network evolution in Upper Devonian-Lower Mississippian Woodford and Mississippian Barnett mudstones: Insights from laboratory thermal maturation and organic petrology. Int. J. Coal Geol. 2018, 190, 3-28. [CrossRef]

58. Budaeva, A.D.; Zoltoev, E.V. Porous structure and sorption properties of nitrogen-containing activated carbon. Fuel 2010, 89, 2623-2627. [CrossRef]

59. Yang, F.; Ning, Z.F.; Wang, Q.; Zhang, R.; Krooss, B.M. Pore structure characteristics of lower Silurian shales in the southern Sichuan Basin, China: Insights to pore development and gas storage mechanism. Int. J. Coal Geol. 2016, 156, 12-24. [CrossRef]

60. Pyun, S.I.; Rhee, C.K. An investigation of fractal characteristics of mesoporous carbon electrodes with various pore structures. Electrochim. Acta 2004, 49, 4171-4180. [CrossRef]

61. Yao, Y.B.; Liu, D.M.; Tang, D.Z.; Tang, S.H.; Huang, W.H. Fractal characterization of adsorption-pores of coals from North China: An investigation on $\mathrm{CH}_{4}$ adsorption capacity of coals. Int. J. Coal Geol. 2008, 73, 27-42. [CrossRef]

62. Donaldson, E.C.; Kendall, R.F.; Baker, B.A.; Manning, F.S. Surface-area measurement of geologic materials. Soc. Pet. Eng. J. 1975, 15, 111-116. [CrossRef]

63. Curtis, J.B. Fractured shale-gas systems. AAPG Bull. 2002, 86, 1921-1938.

64. Li, Y.; Wang, Z.S.; Pan, Z.J.; Niu, X.L.; Yu, Y.; Meng, S.Z. Pore structure and its fractal dimensions of transitional shale: A cross-section from east margin of the Ordos Basin, China. Fuel 2019, 241, 417-431. [CrossRef]

65. Pfeifer, P.; Wu, Y.J.; Cole, M.W.; Krim, J. Multilayer adsorption on a fractally rough surface. Phys. Rev. Lett. 1989, 62, 1997-2000. [CrossRef] [PubMed]

66. Hu, H.Y.; Hao, F.; Lin, J.F.; Lu, Y.C.; Ma, Y.Q.; Li, Q. Organic matter-hosted pore system in the Wufeng-Longmaxi $\left(\mathrm{O}_{3} \mathrm{~W}-\mathrm{S}_{1} \mathrm{l}\right)$ shale, Jiaoshiba area, Eastern Sichuan Basin, China. Int. J. Coal Geol. 2017, 173, 40-50. [CrossRef]

67. Zhang, L.C.; Lu, S.F.; Jiang, S.; Xiao, D.S.; Chen, L.; Liu, Y.; Zhang, Y.; Li, B.; Gong, C. Effect of shale lithofacies on pore structure of the Wufeng-Longmaxi shale in southeast Chongqing, China. Energy Fuels 2018, 32, 6603-6618. [CrossRef]

68. Slatt, R.G.; O'Brien, N.R. Pore types in the Barnett and Woodford gas shales: Contribution to understanding gas storage and migration pathways in fine-grained rocks. AAPG Bull. 2011, 95, 2017-2030. [CrossRef]

69. Chen, S.B.; Han, Y.F.; Fu, C.Q.; Zhang, H.; Zhu, Y.M.; Zuo, Z.X. Micro and nano-size pores of clay minerals in shale reservoirs: Implication for the accumulation of shale gas. Sediment. Geol. 2016, 342, 180-190. [CrossRef]

70. Milliken, K.L.; Rudnicki, M.; Awwiller, D.N.; Zhang, T.W. Organic matter-hosted pore system, Marcellus Formation (Devonian), Pennsylvania. AAPG Bull. 2013, 97, 177-200. [CrossRef]

71. Pommer, M.; Milliken, K. Pore types and pore-size distributions across thermal maturity, Eagle Ford Formation, southern Texas. AAPG Bull. 2015, 99, 1713-1744. [CrossRef]

72. Guo, H.J.; He, R.L.; Jia, W.L.; Peng, P.A.; Lei, Y.H.; Luo, X.R.; Wang, X.; Zhang, L.; Cheng, J. Pore characteristics of lacustrine shale within the oil window in the Upper Triassic Yanchang Formation, southeastern Ordos Basin, China. Mar. Pet. Geol 2018, 91, 279-296. [CrossRef]

(C) 2019 by the authors. Licensee MDPI, Basel, Switzerland. This article is an open access article distributed under the terms and conditions of the Creative Commons Attribution (CC BY) license (http:// creativecommons.org/licenses/by/4.0/). 